\title{
Establishment of oral squamous cell carcinoma cell line and magnetic bead-based isolation and characterization of its CD90/ CD44 subpopulations
}

\author{
Marketa Svobodova1,2,3, Martina Raudenska1,3, Jaromir Gumulec ${ }^{1,3}$, Jan Balvan ${ }^{1}$, \\ Michaela Fojtu', Monika Kratochvilova ${ }^{1,3}$, Hana Polanska1,2,3, Zuzana Horakova ${ }^{4}$, \\ Rom Kostrica ${ }^{4}$, Petr Babula ${ }^{1}$, Zbynek Heger ${ }^{3,5}$ and Michal Masarik ${ }^{1,2}$ \\ ${ }^{1}$ Department of Physiology, Faculty of Medicine, Masaryk University, CZ-62500 Brno, Czech Republic \\ ${ }^{2}$ Department of Pathological Physiology, Faculty of Medicine, Masaryk University, CZ-62500 Brno, Czech Republic \\ ${ }^{3}$ Central European Institute of Technology, Brno University of Technology, CZ-61600 Brno, Czech Republic \\ ${ }^{4}$ Department of Otorhinolaryngology and Head and Neck Surgery, St. Anne's Faculty Hospital, CZ-65691 Brno, Czech Republic \\ ${ }^{5}$ Department of Chemistry and Biochemistry, Mendel University in Brno, CZ-61300 Brno, Czech Republic \\ Correspondence to: Michal Masarik, email: masarik@med.muni.cz \\ Keywords: head and neck neoplasms, coculture techniques, cell line, tumor, carcinoma \\ Received: May 24, $2017 \quad$ Accepted: June 28, $2017 \quad$ Published: August 03, 2017 \\ Copyright: Svobodova et al. This is an open-access article distributed under the terms of the Creative Commons Attribution Li- \\ cense 3.0 (CC BY 3.0), which permits unrestricted use, distribution, and reproduction in any medium, provided the original author \\ and source are credited.
}

\section{ABSTRACT}

In this study, we describe the establishment of the human papillomavirus 18-positive, stage II, grade 1, T2NOMO head and neck tumor primary cell line derived from oral squamous cell carcinoma of a non-smoking patient by using two different protocols. Furthermore, a preparation of subpopulations derived from this primary cell line according to the cluster of differentiation molecules CD44/CD90 status using magnetic bead-based separation and their characterization was performed. Impedancebased real-time cell analysis, enzyme-linked immunsorbant assay (ELISA), woundhealing assay, flow-cytometry, gene expression analysis, and MTT assay were used to characterize these four subpopulations $\left(\mathrm{CD} 44^{+} / \mathrm{CD}^{-} 0^{-}, \mathrm{CD}_{4} 4^{-} / \mathrm{CD}^{-} 0^{-}, \mathrm{CD} 4^{+} / \mathrm{CD} 0^{+}\right.$, $\left.\mathrm{CD}^{-} 4^{-} / \mathrm{CD}^{-} \mathrm{O}^{-}\right)$. We optimised methodics for establishement of primary cell lines derived from oral squamous cell carcinoma tissue samples and subsequent separation of mesenchymal (CD90+) and epithelial (CD90-) types of tumorous cells. Primary cell line prepared by using trypsin proteolysis was more viable than the one prepared by using collagenase. According to our results, CD90 separation is a necessary step in preparation of permanent tumor-tissue derived cell lines. Based on the wound-healing assay, CD44+ ${ }^{+}$cells exhibited stronger migratory capacity than CD44- subpopulations. $\mathrm{CD}_{4}{ }^{+}$subpopulations had also significantly higher expression of BIRC5 and SOX2, lower expression of FLT1 and IL6, and higher levels of basal autophagy compared to CD44subpopulations. Furthermore, co-cultivation experiments revealed that CD44-/CD90+ cells supported growth of epithelial tumor cells $\left(\mathrm{CD}^{4} 4^{+} / \mathrm{CD}^{-} 0^{-}\right)$. On the contrary, factors released by $\mathrm{CD}^{4} 4^{+} / \mathrm{CD} 90^{+}$type of cells seem to have rather inhibiting effect. The most cisplatin-resistant subpopulation with the shortest doubling time was $\mathrm{CD}^{-} 4^{-} / \mathrm{CD}^{-} 0^{+}$, but this subpopulation had a low migratory capacity.

\section{INTRODUCTION}

Head and neck squamous cell carcinoma (HNSCC) is the sixth most frequent cancer worldwide. Regardless of advances in diagnostic methods and therapy, survival of HNSCC remains almost unchanged with treatment resistance and metastases being the most important indicator of adverse outcome [1]. A recently disclosed 
significant problem is the distinct cellular heterogeneity in the HNSCC tumor tissues that may contribute to formation of metastases or treatment resistance [2]. Recent data suggests that many potential cancer stem cell (CSC) markers are differentially expressed in different subpopulations of cells derived from a particular tumor [3]. One of the relevant characteristics of HNSCC subpopulations is the selective expression of surface receptors. In the context of HNSCC, CD44 and CD90 molecules are extensively discussed [4-6].

Surface glycoprotein CD44 is involved in cell-cell interactions, cell migration, and adhesiveness [7]. CD44 receptors are connected to the signalling cascade of EGFR and the PI3K/Akt and thus can significantly affect tumor progression [8]. The $\mathrm{CD} 44^{+}$phenotype is associated with head and neck, prostate, pancreatic, and breast cancerinitiator cells [9]. It has been also revealed that CD44 is important for metastasis as demonstrated on non-metastatic rat glioma cells. Those cells obtained metastatic ability when CD44 was over-expressed [10]. It was revealed that HNSCC cells positive for CD44 have the ability to produce tumors in immunocompromised mice. $\mathrm{CD} 44^{+}$cells are therefore often referred to as the CSCs [11, 12]. On the other hand, Lim et al. study puts the use of CD44 as a CSCs marker into question as they observed that both CD44+ and CD44- cells extracted from squamospheres are able to regenerate these spheres [13]. Nevertheless, CD44+ cancer cell population in primary HNSCC is comprised of less than $10 \%$ of bulk tumor [14] and HNSCC-driven squamospheres possessed enriched CD44+ cell population (53\%) [13]. Furthermore, reduced CD44 expression resulted in a decreased proliferation and in an altered morphology of colonies suggesting a loss of stem cell character [15]. Moreover, CD44 expressed on cancer-associated fibroblasts (CAFs) seems to support the stemness and resistance of neighbouring malignant cells [16].

CD90 (also called THY1) was identified in the thymus as a T-cell differentiation and maturation marker [17], nevertheless human fibroblasts and cancer stromal cells also express abundant CD90 on their surface [18]. Immunohistochemical analysis showed overexpression of CD90 in cancer-associated stroma compared with non-cancer tissue stroma [17]. Furthermore, frequency of CD90-positive cells in HNSCC directly correlates with tumor volume [19]. Moreover, mesenchymal marker CD90 expressed on epithelial cells could be a marker of epithelial-mesenchymal transition (EMT) [4]. Lu et al. also suggested that CD90 could serve as an anchor used by carcinoma stem cells to attach tumor-associated monocytes and macrophages [20].

In this study, we describe the establishment of the head and neck tumor primary cell line derived from oral squamous cell carcinoma in a HPV18-positive, nonsmoking patient (stage II, grade 1, T2N0M0) by using two different protocols. Furthermore, a preparation of subpopulations derived from this primary cell line according to the CD44/CD90 status using magnetic beadbased separation and their characterization was performed.

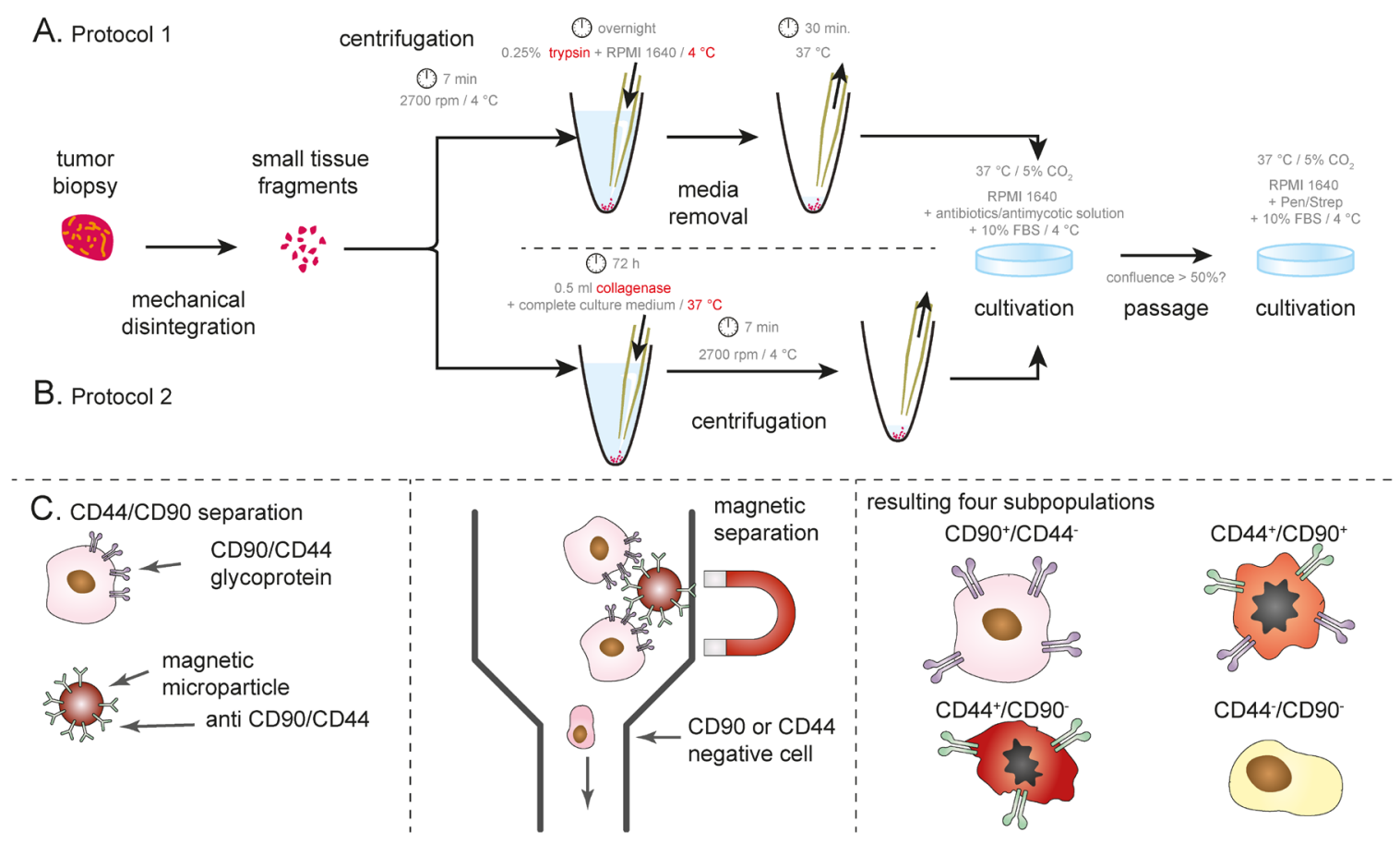

Figure 1: Schematic depiction of isolation protocol. (A) Protocol 1 using trypsin, (B) collagenase-based isolation protocol. (C) Magnetic bead-based separation according CD44/CD90 surface antigens. Both positive- and negative-separation was utilized in order to obtain CD44/CD90 -positive and -negative cells. For details, see Materials and Methods. 
We also present an easy and cheap method for evaluation of the effects of factors released by distinct subpopulations in tumor tissue on cancer cell growth. In this study, we do not aspire to draw general principles of cancerogenesis and cellular interactions in tumor tissue. We would rather offer interesting methodics, procedures, and a new approach for cancer research.

\section{RESULTS}

\section{Clinico-pathological characteristics of patient}

The primary cell line was derived from tumor tissue taken from localized oral squamous cell carcinoma in a $\mathrm{HPV}^{+}$(HPV16 ; HPV18 ${ }^{+}$), non-smoking male-patient (T2N0M0, stage II, grade I). The patient was at the age of 57 with $\mathrm{BMI}=22$, had no previous history of tumors, no diabetes mellitus, hypertension, heart ischemia, or chronic kidney disease. This patient has also not undergone stroke or myocardial infarction. This patient did not receive preoperative radiotherapy or chemotherapy. Patient achieved a complete remission after surgery.

\section{Primary cell line establishment and characterization}

The cell line was prepared by using two protocols; See the section Primary culture establishing and culture conditions. Primary cell line prepared according to the Protocol 2 was not as viable and the cell line designated 132P1 was successfully established according to the Protocol 1 (for details see "Primary culture establishing and culture conditions" section). The growth curve for the primary cell line $132 \mathrm{P} 1$ was as follows: lag phase
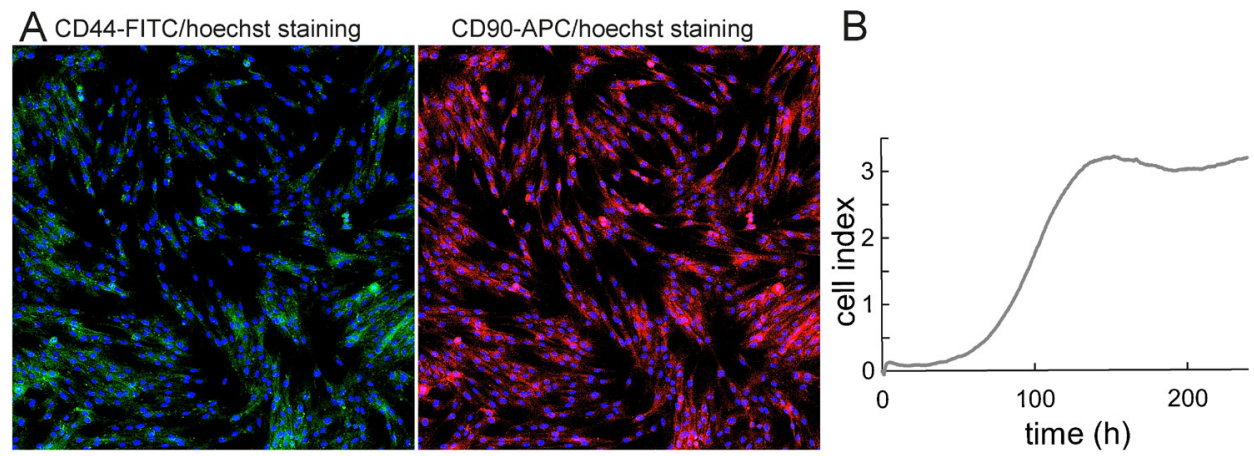

Figure 2: Fluorescence microscopy and growth curve of 132P1 unseparated primoculture. (A) CD44 and CD90 staining of the unseparated cell line $132 \mathrm{P} 1$ after passage 15 . Fluorescent staining revealed prevailing representation of CD $90^{+}$cells; $10 \times$ magnification. (B) Growth profile of unseparated cell line 132P1 using real-time cell analyser demonstrated as a dimensionless unit "cell index".
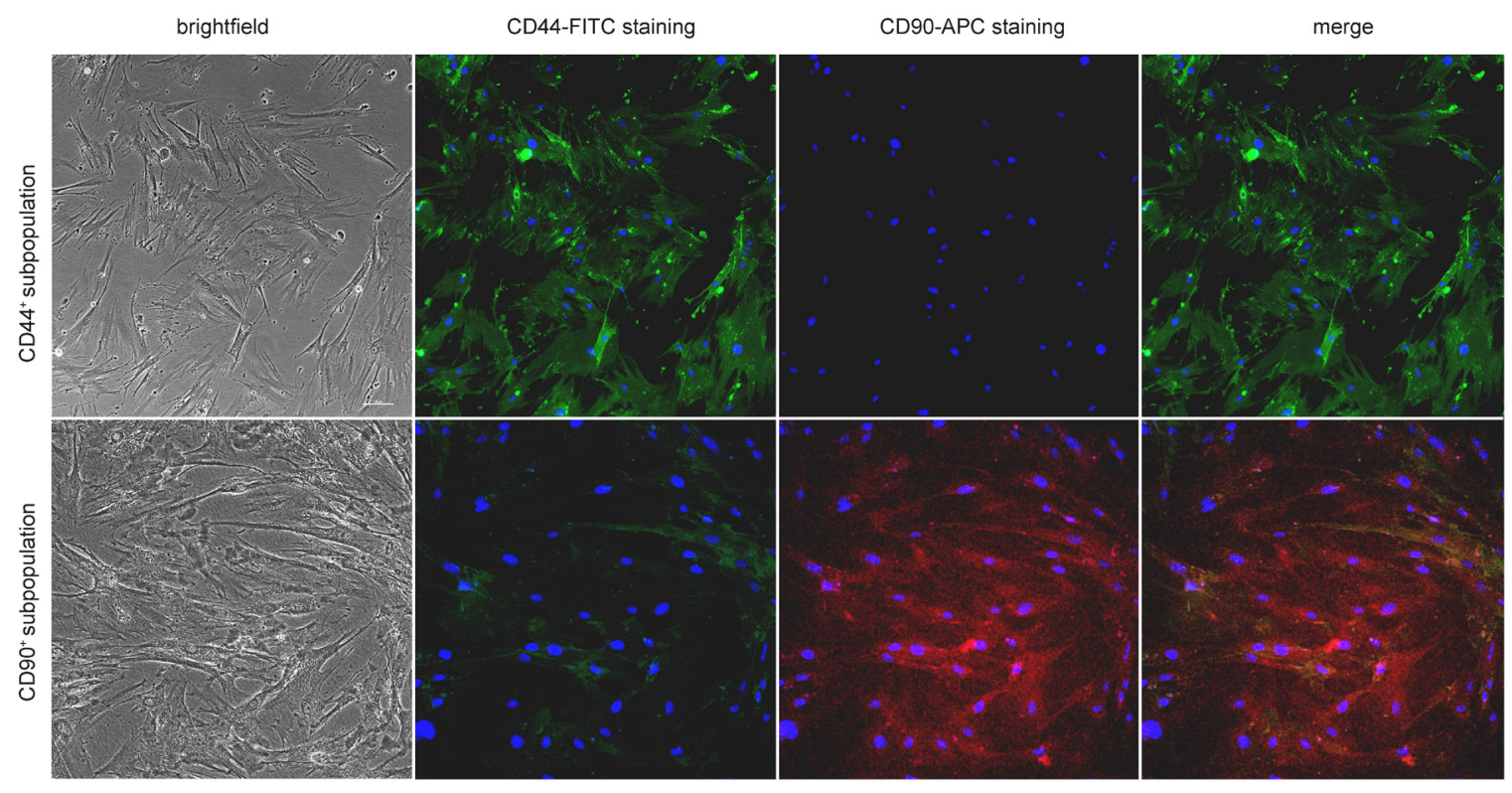

Figure 3: Fluorescent stainging of CD44 and CD90 in separated subpopulations. Fluorescence confirms specificity of the sorting protocol; $20 \times$ magnification. 
$87 \mathrm{~h}$, exponential phase $25 \mathrm{~h}$, and plateau phase after the 112th h. The doubling time was $22 \mathrm{~h}$ (Figure 2B). In our established primary cell line, other subpopulations were gradually overgrown by CD90 $0^{+}$cells (Figure 2A).

\section{Morphology, growth and migratory characteristics of subpopulations}

In the next step, the primary cell line 132P1 was separated according to the CD44 and CD90 status $\left(\mathrm{CD} 44^{+} / \mathrm{CD} 0^{-}, \mathrm{CD}_{4} 4^{-} / \mathrm{CD}^{-} 0^{-}, \mathrm{CD}_{4} 4^{+} / \mathrm{CD} 90^{+}, \mathrm{CD}_{4}{ }^{-} /\right.$ $\mathrm{CD}^{+} 0^{+}$. Separation according to expression of CD44 and CD90 molecules was verified by CD44-FITC/CD90APC fluorescent staining (see Figure 3). After separation of four subpopulations, all four types of subpopulations were able to grow long-term in cell culture (18 passages). Nevertheless, after 18 th $\mathrm{h}$ and 20 th $\mathrm{h}$ passage, respectively, $\mathrm{CD}^{-} 4^{-} / \mathrm{CD}^{-} 0^{-}$and $\mathrm{CD} 44^{-} / \mathrm{CD}^{-} 0^{+}$subpopulations have slowed down their growth extremely and nearly stopped dividing, which was not observed in CD44 subpopulations.

The growth curve for $\mathrm{CD} 44^{-} / \mathrm{CD} 90^{+}$subpopulation was as follows: lag phase $80 \mathrm{~h}$, exponential phase $37 \mathrm{~h}$, and plateau phase after the $117 \mathrm{th} \mathrm{h}$. As soon as cells proceeded into the exponential growth during the exponential phase, the doubling time was measured, because the population is most uniform and cell viability is high in this phase. The doubling time was $26 \mathrm{~h}$ (Figure 4A). Morphology of this subpopulation is shown in the Figure 4B. The growth curve for $\mathrm{CD}_{4} 4^{+} / \mathrm{CD} 90^{+}$subpopulation was as follows: lag phase $74 \mathrm{~h}$, exponential phase $20 \mathrm{~h}$, and plateau phase after the 94th hour. The doubling time was $30 \mathrm{~h}$ (Figure 4E). Morphology of this subpopulation is shown in the Figure $4 \mathrm{~F}$. The growth curve for $\mathrm{CD} 44^{-} / \mathrm{CD} 90^{-}$subpopulation was as follows: lag phase $80 \mathrm{~h}$, exponential phase $40 \mathrm{~h}$, and plateau phase after the 120th hour. The doubling time was $34 \mathrm{~h}$ (Figure 4I). Morphology of this subpopulation is shown in the Figure 4J. The growth curve for $\mathrm{CD}_{4} 4^{+} /$
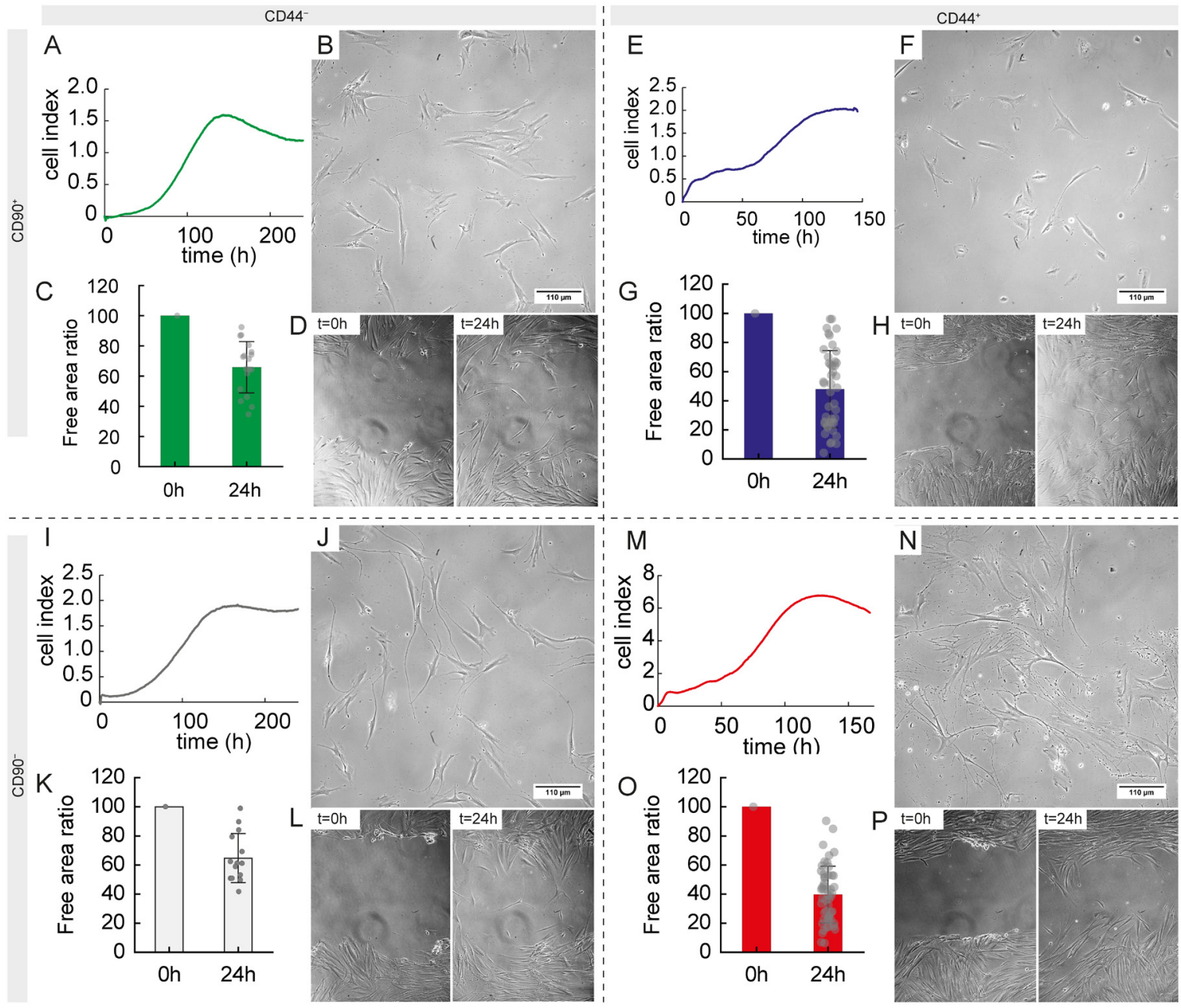

Figure 4: Morphological, growth and migratory characteristics of separated subpopulations according to CD44/CD90 features. (A, E, I, M) Growth profile using real-time cell analyser. (B, F, J, N) Phase contrast microscopy of separated subpopulations, 20× magnification. $(\mathbf{C}, \mathbf{G}, \mathbf{K}, \mathbf{O})$ Wound healing (scratch) assay, percentage of free area (higher value mean slower migratory potential and thus lower invasiveness). (D, H, L, P) Representative phase contrast images of wound healing assay used for analysis. 10× magnification A-D, CD44-/CD90 ${ }^{+}$subpopulation, E-H, CD44 $/ \mathrm{CD} 90^{+}$subpopulation, I-L, CD44-/CD90 subpopulation, M-P, CD44 ${ }^{-} / \mathrm{CD} 90^{-}$subpopulation. 
$\mathrm{CD}^{-}$subpopulation was as follows: lag phase $68 \mathrm{~h}$, exponential phase $25 \mathrm{~h}$, and plateau phase after the 92nd $\mathrm{h}$. The doubling time was $30 \mathrm{~h}$ (Figure 4M). Morphology of this subpopulation is shown in the Figure $4 \mathrm{~N}$.

In the next step, migratory capacity of subpopulations was assessed using a wound healing assay after $24 \mathrm{~h}$. Using univariate testing, CD44 status affected the migratory potential significantly, where cells positive for this antigen demonstrated 1.5-fold higher migratory potential, $F(1,123)=23.46 ; p<0.001$. CD90 status did not affected the migratory capacity significantly, $\mathrm{F}(1,123)=1.10, \mathrm{p}=0.29$. Nevertheless, CD44 ${ }^{+} / \mathrm{CD}^{-} 0^{-}$ cells exhibited the strongest migratory capacity closely followed by $\mathrm{CD}_{4} 4^{+} / \mathrm{CD} 90^{+}$subpopulation (1.2-fold lower, $\mathrm{p}=0.67)$; see Figure 4C, 4D, 4G, 4H, 4K, 4L, 4O, 4P.
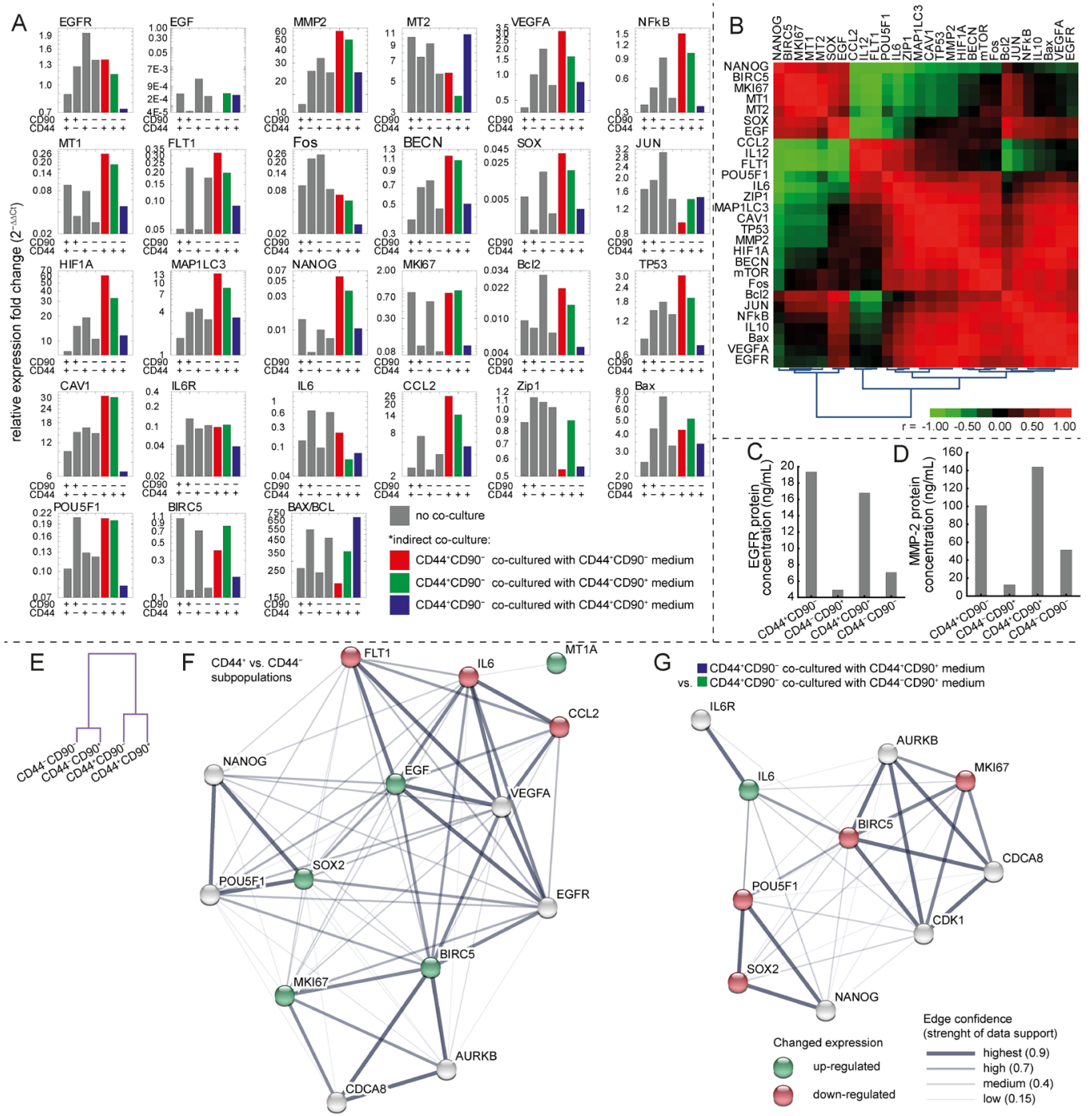

Figure 5: Gene expression in subpopulations and in co-culture experiment. (A) Gene expression using qRT-PCR. Gray bars indicate measurements without any type of co-culture, coloured bars indicate measurement of gene expression of $\mathrm{CD}_{4} 4^{+}$. $\mathrm{CD}^{-} 0^{-}$subpopulation affected by medium from particular subpopulation (for details see Materials and Methods section). (B) Clustered correlation heatmap based on a gene expression of subpopulations not exposed to co-culture experiment. (C) ELISA of EGFR in particular subpopulations. (D) ELISA of MMP-2 in particular subpopulations. (E) Hierarchical clustering of cases (subpopulations) based on the gene expression, no co-culture only. See the substantial effect of CD44 status on the gene expression. (F) Interactome network showing the genes, which expression differs significantly between $\mathrm{CD} 44^{+}$vs CD $44^{-}$ subpopulations (green and red for up-, and down-regulation), analyzed using STRING software (version 10.0). Line thickness indicate strenght of data support. (G) Interactome network showing the genes, which expression differs significantly between $\mathrm{CD} 44^{+} \mathrm{CD} 90^{-}$co-cultured with $\mathrm{CD} 44^{+} \mathrm{CD} 90^{+}$medium and $\mathrm{CD} 44^{+} \mathrm{CD} 90^{-}$co-cultured with $\mathrm{CD} 44^{-} \mathrm{CD} 90^{+}$medium (groups coded blue and green at Figure 5A). For detailed statistical results, see Supplementary Appendix 2, for functional enrichments in the network of selected genes, see Supplementary Appendix 3. 


\section{Characterization of basal cell death in subpopulations}

Double-staining with fluorescein isothiocyanate (FITC)/propidium iodide (PI) was undertaken to determine basal levels of apoptosis and necrosis in particular subpopulations. First, non-stained cells (control) were analysed using flow-cytometry to set the annexin V /PI gating regions (Supplementary Appendix 1A). Consequently, non-treated cells from different subpopulations were analysed (Supplementary Appendix 1B). Four different phenotypes were distinguished: (a) annexin V-/PI- (lower left quadrant, Q3); (b) annexin $\mathrm{V}+/ \mathrm{PI}-$ (lower right quadrant, $\mathrm{Q} 4$, usually presumed as apoptotic); (c) annexin $\mathrm{V}-/ \mathrm{PI}+$ (upper left quadrant, Q1); (d) annexin $\mathrm{V}+/ \mathrm{PI}+$ (upper right quadrant, Q2, usually presumed as necrotic).

Average frequency of annexin $\mathrm{V}+/ \mathrm{PI}-$ cells was as follows: $14.9 \%$ in $\mathrm{CD}_{4}-/ \mathrm{CD} 90^{+}$subpopulation; $23 \%$ in $\mathrm{CD}_{4} 4^{+} / \mathrm{CD} 90^{+}$subpopulation; $12.3 \%$ in $\mathrm{CD} 44^{+} / \mathrm{CD} 90^{-}$ subpopulation; $12.6 \%$ in $\mathrm{CD}_{4} 4^{-} / \mathrm{CD} 90^{-}$subpopulation. In sum, frequency of annexin $\mathrm{V}+\mathrm{PI}-$ cells in $\mathrm{CD}^{-} 0^{-}$ subpopulations was lower than in $\mathrm{CD} 90^{+}$ones.
Furthermore, autophagosome formation in subpopulations was detected using the CYTO-ID Autophagy Detection Kit (Supplementary Appendix 1C). The levels of autophagy (CYTO-ID ${ }^{+}$population) in subpopulations were as follows: $6.2 \%$ in $\mathrm{CD} 44^{-} / \mathrm{CD} 90^{+}$ subpopulation; $7.8 \%$ in $\mathrm{CD}_{4} 4^{+} / \mathrm{CD} 90^{+}$subpopulation; $7.9 \%$ in $\mathrm{CD}_{4} 4^{+} / \mathrm{CD} 90^{-}$subpopulation; $5.5 \%$ in $\mathrm{CD} 44^{-} /$ CD90-subpopulation. In sum, the frequency of autophagy in $\mathrm{CD}_{4} 4^{+}$subpopulations was slightly higher than in $\mathrm{CD} 44^{-}$ones.

\section{Expression patterns of HNSCC marker genes in $\mathrm{CD}^{+} / \mathrm{CD}^{+}{ }^{+}$; $\mathrm{CD}^{-} 4^{-} / \mathrm{CD}^{+}{ }^{+}$; $\mathrm{CD}{ }^{+} / \mathrm{CD}^{-}{ }^{-}$; $\mathrm{CD}^{-} / \mathrm{CD}^{-}{ }^{-}{ }^{-}$subpopulations}

This part of study is focused on the expression of genes potentially important for the development of cancer: 1) acquisition of autonomous proliferative signalling $(E G F R, E G F)$; 2) proliferative activity of tumor cells $(M K I 67) ; 3)$ cell cycle and cell death modifications $(B C L 2$, BAX, FOS, JUN, TP53, BIRC5, MAP1LC3B, BECN1, NFKB1, MTOR, CAV1); 4) angiogenesis (VEGF/FLT1); 5) metastatic potential (MMP2); 6) oxidative stress response

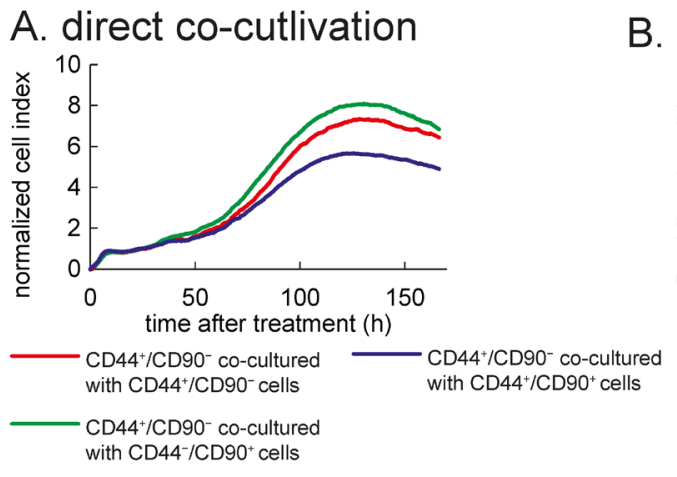

\section{C. indirect co-cutlivation}
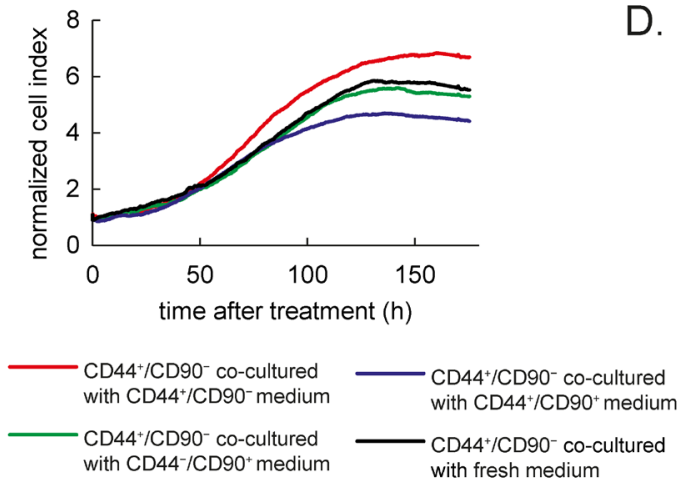
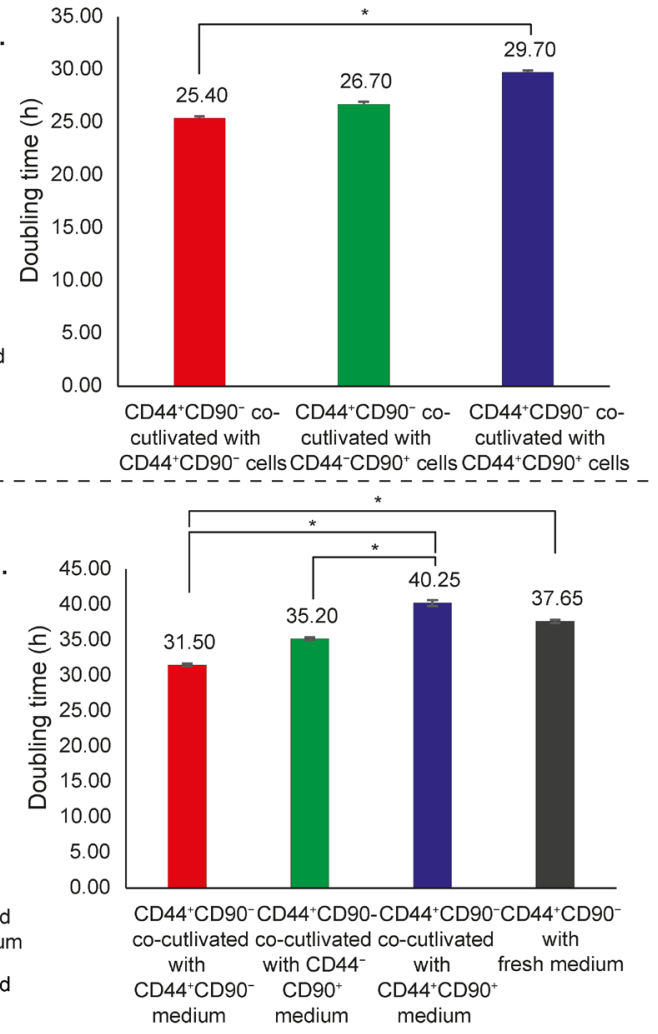

Figure 6: Co-culture experiment. (A) Direct co-culture (measurement of the $\mathrm{CD} 44^{+} / \mathrm{CD} 90^{-}$growth characteristics affected by cells in the insert without a direct contact). Real time cell analyser (RTCA). (B) Doubling time of CD $44^{+} / \mathrm{CD}^{-} 0^{-}$cells affected by particular subpopulation in a direct co-culture experiment. (C) Indirect co-culture (measurement of the $\mathrm{CD} 44^{+} / \mathrm{CD} 90^{-}$growth characteristics affected by a medium from particular subpopulations in a common RTCA setup). (D) Doubling time of CD44 ${ }^{+} / \mathrm{CD}^{-} 0^{-}$affected by indirect coculture. Asterisk indicate significant difference at $\mathrm{p}<0.05$. 
(MT1A, MT2A, ZIP1, HIF1A), pluripotency genes (NANOG, SOX2, POU5F1); and 7) immune response (CCL2, IL6, IL6R).

Abundantly expressed genes in all studied subpopulations were $M M P 2, H I F 1 A, M T 2 A$, and CAV1. Subpopulation expressing CD44 had significantly higher expression of BIRC5 and SOX2 (CD44 ${ }^{+} / \mathrm{CD} 90^{+}$vs. CD $44^{-} /$ $\mathrm{CD} 90^{+} \mathrm{p}=0.002$ resp. $\mathrm{p}=0.017 ; \mathrm{CD} 44^{+} / \mathrm{CD} 90^{-}$vs. $\mathrm{CD} 44^{-} /$ $\mathrm{CD} 90^{+} \mathrm{p}=0.009$ resp. $\mathrm{p}=0.006$ ). No significant changes in expression between $\mathrm{CD} 44^{-} / \mathrm{CD} 90^{+}$and $\mathrm{CD} 44^{-} / \mathrm{CD} 90^{-}$ or $\mathrm{CD}_{4} 4^{+} / \mathrm{CD} 90^{-}$and $\mathrm{CD} 44^{+} / \mathrm{CD} 90^{+}$were found. Thus, CD90 status did not affect the expression of studied genes significantly (see Supplemantary Appendix 2). On the contrary, $\mathrm{CD} 44^{+}$subpopulations had lower expression of FLT1 and IL6 compared to CD44 subpopulations (CD44 $4^{+}$ $\mathrm{CD} 90^{+}$vs. $\mathrm{CD}_{4} 4^{-} / \mathrm{CD} 90^{+} \mathrm{p}=0.03$ resp. $\mathrm{p}=0.0001 ; \mathrm{CD} 44^{+} /$ $\mathrm{CD}^{-} 0^{-}$vs. $\mathrm{CD}^{-} 4^{-} / \mathrm{CD} 0^{+} \mathrm{p}=0.006$ resp. 0.0001), No significant changes in expression between $\mathrm{CD}^{-} 4^{-} / \mathrm{CD} 90^{+}$ and $\mathrm{CD} 44^{-} / \mathrm{CD} 90^{-}$were found (see the Figure $5 \mathrm{~A}$ ).

Based on the co-expression pattern of genes, hierarchical clustering revealed that there are two major clusters of subpopulations based on the CD44 status (Figure 5E). Nearness of CD44 $4^{+}$subpopulations in gene expression is clearly highlighted, while CD90 status did not affect the overall expression pattern substantially. Subsequently, interactome network showing the genes whose expression differs significantly between $\mathrm{CD} 44^{+}$vs CD44- ${ }^{-}$subpopulations was performed using STRINGDB software (Figure 5F). Based on this interactome network, it was revealed that biological processes relating to proliferation, migration, stemness, and angiogenesis were significantly affected by differentially expressed set of genes, (e.g GoMiner GO.0030335, GO.0050678, GO.0001525, GO.0022402, GO.0048646, GO.0016477). For the full list of significantly affected pathways and cellular components see Supplementary Appendix 3.

According to the gene expression correlation analysis (see the Figure 5B), the proliferation marker $M K I 67$ was in no or even in a negative correlation with proliferative stimuli such as IL6, VEGFA, or CCL2. Aditionally, the expression of receptors such as EGFR and FLT1 was not in a significant positive correlation with their ligands (EGF, IL6, and VEGFA). This implies that part of these factors could be exploited by the subpopulation in tumor mass which is not responsible for their production. For these reasons, experiments with cocultivation were performed.

Furthermore, protein expression of MMP-2 and EGFR was assessed by ELISA (see Figure 5C and 5D). According to ELISA, CD44 $4^{+}$subpopulations had higher levels of both tested proteins compared to CD44-. The lowest expression of both MMP-2 and EGFR was detected in $\mathrm{CD}_{4} 4^{-} \mathrm{CD} 90^{+}$subpopulation of cells.

\section{Direct co-culture}

After $24 \mathrm{~h}$ of incubation, the inserts (containing $\mathrm{CD}_{4} 4^{+} / \mathrm{CD} 90^{-}$; $\mathrm{CD} 44^{+} / \mathrm{CD} 90^{+}$; or $\mathrm{CD} 44^{-} / \mathrm{CD} 90^{+}$cells) were lowered into the E-plate (containing $\mathrm{CD}_{4} 4^{+} /$ $\mathrm{CD}^{-}{ }^{-}$cells; anticipated as epithelial tumor cells). In this arrangement, two tested subpopulations were able to exchange factors released to medium and to influence each other's growth by paracrine signaling, but were not able to be in a direct contact. The grow response curve of the "lower" $\mathrm{CD} 44^{+} / \mathrm{CD} 90^{-}$population was recorded. The rate of proliferation was monitored in real time using xCELLigence system (see Figure 6A). CD44-/CD90- cells were not included in co-cultivation experiments, because they were not able to grow in inserts. Nevertheless, according to our expression and migration analysis, no significant differences between $\mathrm{CD} 44^{-} / \mathrm{CD} 90^{-}$and $\mathrm{CD} 44^{-} /$ $\mathrm{CD} 90^{+}$subpopulations were observed.

Doubling time of $\mathrm{CD} 44^{+} / \mathrm{CD} 90^{-}$cells co-cultivated with $\mathrm{CD} 44^{+} / \mathrm{CD} 90^{-}$cells was significantly shorter than doubling time of $\mathrm{CD} 44^{+} / \mathrm{CD} 90^{-}$cells co-cultivated with $\mathrm{CD} 44^{+} / \mathrm{CD} 90^{+}(25.40 \pm 0.16 \mathrm{~h}$ vs. $29.70 \pm 0.20 \mathrm{~h}, \mathrm{p}=$ 0.028 ); see Figure 6B. Doubling time after co-cultivation with CD44-/CD90+ was shorter as well, but below the statistical significance $(26.70 \pm 0.22 \mathrm{~h}, \mathrm{p}=0.06)$. Doubling time of $\mathrm{CD} 44^{+} / \mathrm{CD} 90^{-}$cells cultivated separately without any co-culture was $30 \mathrm{~h}$; (see the section "Morphology, growth and migratory characteristics of subpopulations").
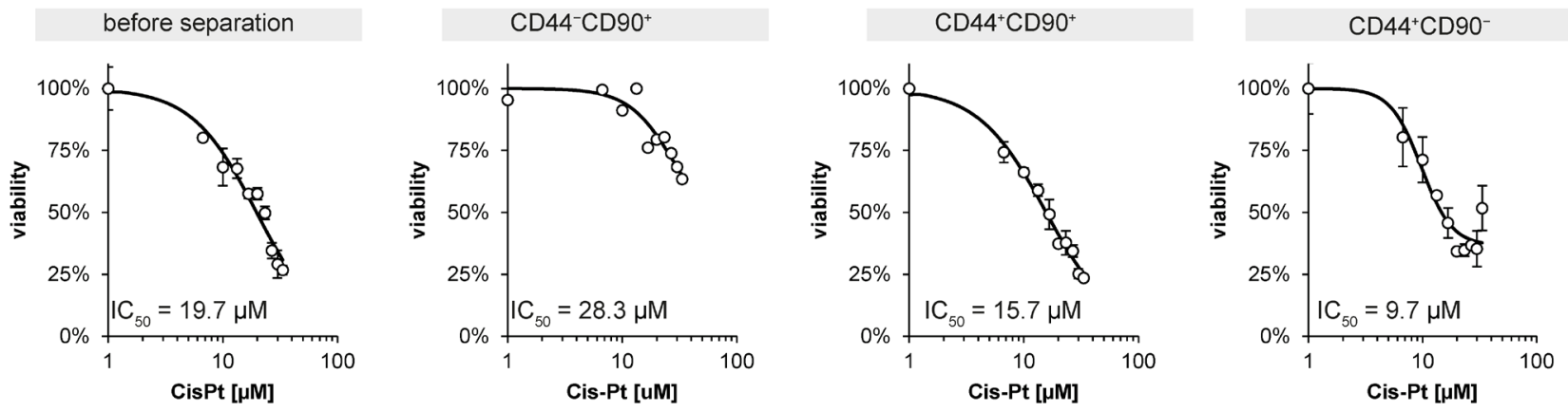

Figure 7: MTT assay of unsorted primoculture and subpopulations exposed to cisplatin treatment. $\mathrm{IC}_{50}$ means the half maximal inhibitory concentration. 
Furthermore, the highest cell index was reached by cocultivation of $\mathrm{CD} 44^{+} / \mathrm{CD}^{-} 0^{-}$cells with $\mathrm{CD} 44^{-} / \mathrm{CD} 90^{+}$. On the contrary, when $\mathrm{CD}_{4} 4^{+} / \mathrm{CD} 90^{-}$were cells co-cultivated with $\mathrm{CD} 44^{+} / \mathrm{CD} 90^{+}$, cell index (CI) value was the lowest. This dimensionless parameter is derived as a relative change in measured electrical impedance to represent cell status. When cells are not present or are not welladhered to the electrodes, the CI is zero. Under the same physiological conditions, when more cells are attached to the electrodes, the CI values are larger. According to our results, factors released by mesenchymal type of cells, which do not express CD44 (CD44 $\left.{ }^{-} / \mathrm{CD}^{+} 0^{+}\right)$, are able to support a growth of $\mathrm{CD} 44^{+} / \mathrm{CD} 90^{-}$type of cells (epithelial tumor cells). Moreover, CD $44^{+} / \mathrm{CD}^{-} 0^{-}$cells also produce factors supporting their own growth.

\section{Indirect co-culture with subpopulation-derived media}

After 24 h-lasting cultivation of CD $44^{+} / \mathrm{CD}^{-}$- cells, medium was removed and replaced with a "foreign" media derived from another $24 \mathrm{~h}$-lasting cultivation to display the effect of: a) $\mathrm{CD}_{4} 4^{-} / \mathrm{CD} 90^{+}$derived medium, b) $\mathrm{CD} 44^{+} /$ CD $90^{+}$derived medium, c) $\mathrm{CD} 44^{+} / \mathrm{CD} 90^{-}$derived medium from different Petri dish, and the effect of d) fresh control RPMI medium. In this arrangement, tested subpopulation was affected by factors released to the medium by other subpopulations (in this arrangement, factors released to medium were not a result of paracrine communication between different cell subtypes like in a direct co-culture experiment). An effect of exhausting of tested medium was also observed. The rate of proliferation was monitored in real time using xCELLigence system (see Figure 6C and 6D). Doubling times of $\mathrm{CD} 44^{+} / \mathrm{CD}^{-} 0^{-}$cells were as follows: a) $35.20 \pm 0.20 \mathrm{~h}$ with $\mathrm{CD} 44^{-} / \mathrm{CD}^{\circ} 0^{+}$-derived medium, b) $40.25 \pm 0.41 \mathrm{~h}$ with $\mathrm{CD} 44^{+} / \mathrm{CD} 90^{+}$-derived medium, c) $31.5 \pm 0.17 \mathrm{~h}$ with $\mathrm{CD} 44^{+} / \mathrm{CD} 90^{-}$-derived medium from different Petri dish, and d) $37.65 \pm 0.22 \mathrm{~h}$ with fresh RPMI medium. Thus, cells supplemented with $\mathrm{CD}_{4}{ }^{+} / \mathrm{CD} 90^{+}$growed significantly slower compared to those supplemented with $\mathrm{CD} 44^{+} / \mathrm{CD} 90^{-}$medium $(p=0.004)$ and those supplemented with $\mathrm{CD} 44^{-} / \mathrm{CD} 90^{+}-$ derived medium $(\mathrm{p}=0.030)$. Furthermore, the highest CI was reached by cultivation with $\mathrm{CD} 44^{+} / \mathrm{CD} 90^{-}$derived medium. CI for $\mathrm{CD}_{4} 4^{-} / \mathrm{CD} 90^{+}$derived medium, and fresh RPMI medium was almost identical. The lowest CI was observed by cultivation with $\mathrm{CD} 44^{+} / \mathrm{CD} 90^{+}$derived medium. Inasmuch as tested medium was used for 24 $\mathrm{h}$ by other cell population, influence of released factors and nutrient exhausting could be presumed. Whereas $\mathrm{CD} 44^{+} / \mathrm{CD} 90^{-}$derived medium from different Petri dish with $\mathrm{CD}_{4} 4^{+} / \mathrm{CD}^{-} 0^{-}$population supported $\mathrm{CD} 44^{+} / \mathrm{CD}^{-}$ growth, $\mathrm{CD} 44^{+} / \mathrm{CD} 90^{+}$derived medium rather inhibited $\mathrm{CD}_{4}{ }^{+} / \mathrm{CD} 90^{-}$cell growth in comparison with fresh medium.
Our qRT-PCR measurement has been performed after $72 \mathrm{~h}$ of $\mathrm{CD} 44^{+} / \mathrm{CD} 90^{-}$cells' cultivation in "foreign" medium in medium derived from $\mathrm{CD} 44^{+} / \mathrm{CD}^{-} 0^{-}$cells previously cultivated $24 \mathrm{~h}$ in a different Petri dish.

Exhausted medium derived from $\mathrm{CD}_{4} 4^{+} / \mathrm{CD} 90^{-}$ cells caused these particular changes in gene expression in comparison with $\mathrm{CD} 44^{+} / \mathrm{CD} 90^{-}$cells in fresh medium (see Figure 5A): (a) Upregulation in FLT1 (5.15 fold change, $\mathrm{p}=0.013$ ), NANOG (4.58 fold change, $\mathrm{p}=0.034)$, CCL2 (4.81 fold change, $\mathrm{p}=0.039$ ), and IL6 (1.85 fold change, $\mathrm{p}=0.0001)$, (b) downregulation in FOS ( 0.25 fold change, $\mathrm{p}=0.024)$.

Medium derived from $\mathrm{CD} 44^{+} / \mathrm{CD} 90^{+}$caused significant downregulation in expression of SOX2 and IL6 ( $\mathrm{p}=0.01$ resp. 0.0001 ) in $\mathrm{CD} 44^{+} / \mathrm{CD} 90^{-}$cells (anticipated epithelial tumor cells) compared with medium derived from other $\mathrm{CD} 44^{+} / \mathrm{CD} 90^{-}$cultivated separately (see Figure 5A).

Medium derived form $\mathrm{CD} 44^{-} / \mathrm{CD} 0^{+}$caused significant downregulation in expression of IL6 $(\mathrm{p}=0.0001)$ in $\mathrm{CD}_{4} 4^{+} / \mathrm{CD}^{-} 0^{-}$cells (anticipated epithelial tumor cells) compared with medium derived from $\mathrm{CD}_{4}{ }^{+} /$ $\mathrm{CD}^{-}$(see Figure 5A).

In conclusion, both tested media derived from mesenchymal subpopulations $\left(\mathrm{CD} 44^{+} / \mathrm{CD} 90^{+}\right.$and $\mathrm{CD}_{4} 4^{-} /$ $\mathrm{CD}^{+} 0^{+}$) were able to decrease expression of IL6 in $\mathrm{CD}_{4} 4^{+} /$ $\mathrm{CD}^{-}$cells in comparison with exhausted medium derived from $\mathrm{CD} 44^{+} / \mathrm{CD}^{-} 0^{-}$cells. The effects on $\mathrm{CD} 44^{+} /$ $\mathrm{CD}^{-} 0^{-}$cells after a treatment with medium derived from $\mathrm{CD}_{4} 4^{+} / \mathrm{CD}{ }^{+}$cells differed significantly (was either higher or lower) when compared with other two types of partially exhausted subpopulation-derived media (compare Figure 5A). For instance, expression of proliferative marker MKI67 triggered by tested medium was almost identical to cultivation with $\mathrm{CD} 44^{+} / \mathrm{CD} 90^{-}$derived medium, CD44 $/ \mathrm{CD} 90^{+}$derived medium, and fresh RPMI medium, which is in accordance with results obtained from xCELLigence system. $\mathrm{CD} 44^{+} / \mathrm{CD} 0^{+}$derived medium rather inhibited MKI67 expression in $\mathrm{CD}^{4} 4^{+} / \mathrm{CD}^{-} 0^{-}$cells (medium derived from $\mathrm{CD} 44^{+} / \mathrm{CD} 90^{+}$caused 0.23 fold change in MKI67 expression in $\mathrm{CD} 44^{+} / \mathrm{CD}^{-} 0^{-}$cells in comparison with medium derived from $\mathrm{CD}^{-} 4^{-} / \mathrm{CD}^{+} 0^{+}$; $\mathrm{p}=0.049$ ). Furthermore, SOX2 and POU5F1 were also significantly down-regulated. Subsequently, interactome network showing the genes whose expression differs significantly between $\mathrm{CD} 44^{+} / \mathrm{CD} 90^{-}$cells co-cultured with $\mathrm{CD}_{4} 4^{+} / \mathrm{CD} 90^{+}$medium vs. $\mathrm{CD} 44^{+} / \mathrm{CD} 90^{-}$co-cultured with CD44 ${ }^{-} / \mathrm{CD} 90^{+}$medium was performed using STRING-DB software (Figure $5 \mathrm{G}$ ). Based on this interactome network, it was revealed that biological processes relating to the cell division, cell cycle, and cellular response to interleukin-6 were significantly affected by differentially expressed set of genes, (e.g GoMiner GO.0051301, GO.0022402, GO.0071354). For the full list of significantly affected pathways and cellular components see Supplementary Appendix 3. 


\section{Viability after cisplatin treatment}

Viability of the primary cell line and the separate subpopulations after cisplatin treatment was tested by using MTT assay in order to assess the degree of resistance of individual subpopulation to this drug. The $\mathrm{IC}_{50}$ of primary cell line $132 \mathrm{P} 1$ for cisplatin was $19.7 \mu \mathrm{M}$. The most resistant subpopulation was $\mathrm{CD}_{4} 4^{-} / \mathrm{CD} 90^{+}(\mathrm{IC} 50=$ $28.3 \mu \mathrm{M})$. Among $\mathrm{CD} 44^{+}$subpopulations, $\mathrm{CD} 44^{+} / \mathrm{CD} 90^{+}$ was more resistant to cisplatin than $\mathrm{CD} 44^{+} / \mathrm{CD} 90^{-}\left(\mathrm{IC}_{50}\right.$ value was $15.7 \mu \mathrm{M}$ and $9.7 \mu \mathrm{M}$, respectively), see Figure 7 .

\section{DISCUSSION}

In this study, we described the establishment of the HNSCC primary cell line designated 132P1 derived from well-differentiated, localized oral squamous cell carcinoma tissue obtained by the primary tumor biopsy and also establishment and characterization of $\mathrm{CD}_{4} 4^{+} /$ $\mathrm{CD} 90^{-}, \mathrm{CD} 44^{-} / \mathrm{CD} 0^{-}, \mathrm{CD} 44^{+} / \mathrm{CD} 90^{+}$, and $\mathrm{CD} 44^{-} /$ $\mathrm{CD}^{-}$cell subpopulations derived from this primary cell line 132P1. Also of note, patient was a HPV18-positive, non-smoker, did not receive preoperative radiotherapy or chemotherapy and achieved a complete remission after surgery. Primary cell line prepared by using trypsin proteolysis was more viable than the one prepared by using collagenase (verified also in further primary cell lines preparations; unpublished results). In our established non-separated primary cell line, other subpopulations were gradually overgrown by mesenchymal $\left(\mathrm{CD} 90^{+}\right.$cells) and therefore non-separated HNSCC tissue-derived cell lines are probably not a good model for testing of treatment response of epithelial cancer cells.

Magnetic bead-based separation was found to be suitable for separation of cells with distinct CDfeatures. All four types of subpopulations were able to grow long-term in cell culture. Nevertheless, after 20th passage, $\mathrm{CD} 44^{-} / \mathrm{CD} 90^{-}$and $\mathrm{CD}^{-} 4^{-} / \mathrm{CD} 90^{+}$subpopulations extremely slowed down their growth and nearly stopped dividing, which was not observed in $\mathrm{CD} 44^{+}$ subpopulations. It implies that $\mathrm{CD}_{4} 4^{+}$cells could be more susceptible to immortalization and therefore more predisposed to establishment of permanent HNSCC cell lines. In accordance with our findings, Pries et al. found CD44 to be constitutively expressed on the surface of eight out of eight tested permanent HNSCC cell lines [21]. The doubling time of our primary cell line and derived subpopulations was rather fast (22-34 h) compared to other human tumor cell lines [22].

There is a growing number of studies that confirm a function of cancer-associated stroma in the carcinogenesis and tumor progression. Zhao et al. findings suggest that the phenotype of cells expressing high levels of CD90 is more tumor-promoting than the phenotype of cells expressing low CD90 [23]. According to our results, factors released by $\mathrm{CD} 90^{+}$type of cells, which do not express CD44, are able to support growth of epithelial tumor cells $\left(\mathrm{CD} 44^{+}\right)$ $\mathrm{CD} 90^{-}$). On the other hand, factors released by $\mathrm{CD}_{4} 4^{+} /$ $\mathrm{CD} 0^{+}$cells into medium seem to have rather inhibitory effect on epithelial tumor cell growth. Inasmuch the frequency of annexin $\mathrm{V}+/ \mathrm{PI}-$ and also annexin $\mathrm{V}+/ \mathrm{PI}+$ cells in $\mathrm{CD} 44^{+} / \mathrm{CD} 90^{+}$subpopulation cultivated separately was higher than in other subpopulations, it is possible that $\mathrm{CD} 44^{+} / \mathrm{CD} 90^{+}$cells are able to produce factors stimulating cell death in neighbouring cells. This observation is not in accordance with Spaeth et al. who showed that CD44 expression on tumor stromal precursors is necessary for their functionality within the tumor microenvironment as tumor supporting, angiogenesis inducing, activated fibroblasts [24]. Taking into account that our patient achieved a complete remission, we can speculate that the maintenance of tumor is a result of interactions in the cancer cell community and that tumor progression depends on the cooperation among all the members of tumor tissue, not just on the aggressiveness of its most abnormal subpopulation.

In our study, self-survival and self-renewal supporting factors such as SOX2, NANOG, and BIRC5 [2527] were highly expressed in $\mathrm{CD} 44^{+} / \mathrm{CD} 90^{+}$subpopulation whereas $\mathrm{CD} 44^{-} / \mathrm{CD} 90^{+}$subpopulation was an important producer of "public goods" such as chemokine (C-C motif) ligand 2 (CCL2) and interleukin-6 (ILO). IL-6 has a possible function in the inducible generation of CSCs and their dynamic balance with non-stem cells [20, 28]. CCL2 supports recruiting of inflammatory monocytes and facilitates metastasis [29]. Furthermore, IL6 and CCL2 are able to support tumor growth, EMT, stem cell migration, and finally treatment resistance [30-34]. Accordingly, we observed the highest cisplatin resistance in $\mathrm{CD} 44^{-} / \mathrm{CD} 90^{+}$ subpopulation. This subpopulation was more cisplatinresistant than our primary unseparated cell line 132P1, which implies important role of this subpopulation in conferring of resistance in whole HNSCC tumor.

The most expressed gene in all subpopulations was matrix metalloproteinase 2 (MMP2). MMPs promote tumor progression and metastasis formation by degradation of the extracellular matrix. Dufour et al showed that transfection of COS-1 cells with MMP-9, MMP-2, or even with a proteolytically inactive mutant of MMP-9 increases cell migration $[35,36]$. ProMMP-2 was also shown to induce vascular endothelial growth factor (VEGF) expression via activation of PI3K/Akt/HIF-1 $\alpha$, which may lead to an increased angiogenesis [37]. Other highly expressed genes in all types of subpopulations were HIF1A, MT2A, and CAV1. HIF1A is known to be involved in hypoxia-induced therapeutic resistance [38], MT2A that has been connected with oxidative stress [39], and CAV1 that has been demonstrated to play an important role in EMT, glucose uptake, lactate accumulation, and ATP production [40-42].

$\mathrm{CD} 44^{+}$subpopulations were characteristic by higher gene expression of $B I R C 5$, and $S O X 2$, protein expression 
of MMP2 and EGFR and by high basal autophagy. On the contrary, CD44 ${ }^{+}$subpopulations had lower expression of FLT1 and IL6. BIRC alias survivin is involved inter alia in the ability to escape from accelerated senescence [43]. Of note, it is possible that senescence-escaped cells may transform into malignant cancer cells by the additional hits of several genes in vivo. Elevated levels of autophagy under basal conditions were observed in pancreatic cancer primary tumors and cell lines. Basal autophagy was shown to act as a cellular energy source and to prevent the accumulation of genotoxic levels of oxidative stress in pancreatic cancer cells. Conversely, inhibition of basal autophagy resulted in tumor regression [44]. Furthermore, the expression of $S O X 2$ gene connected with pluripotency [45] was abundant in both $\mathrm{CD}_{4} 4^{+}$subpopulations. It could mean that more than one subpopulation with stem cell abilities may exist in the same tumor (CD44 ${ }^{+} / \mathrm{CD}^{-} 0^{-}$ epithelial cancer stem cells [46] and CD44 $/$ CD $90^{+}$tumor stem cells formed by EMT). Surprisingly, another studied pluripotency gene POU5F was abundantly expressed in the $\mathrm{CD} 44^{-} / \mathrm{CD}^{+} 0^{+}$subpopulation. Mitchell et al. have recently showed that POU5F-induced plasticity in human fibroblasts results in a capability of responding to changes in the extracellular environment that could ultimately lead to the alteration of cell fate. This molecular state of human fibroblasts' plasticity was characterized by elevated levels of developmental genes, but not other genes involved in pluripotency [47]. We can speculate that POU5F expression in non-stem $\mathrm{CD} 44^{-} / \mathrm{CD} 90^{+}$subpopulation demonstrates a "willingness" of this subpopulation to be manipulated by aggressive tumor cells.

Radiotherapy represents the standard treatment for head and neck squamous cell carcinoma (HNSCC) patients, often in combination with surgery. Nowadays, chemoradiotherapy has been incorporated in the treatment of advanced tumors. Cisplatin is the most common agent [11]. Based on the doubling time assessment, $\mathrm{CD}^{4} 4^{-} / \mathrm{CD} 90^{+}$cells proliferated more rapidly than other cells and thus, they might be preferentially eliminated by cisplatin therapy. Nevertheless, the CD44-/CD90 ${ }^{+}$ subpopulation showed the lowest sensitivity to cisplatin compared to other subpopulations and even compared to the primary cell line. This could be associated with a high expression of FLT1 by this subpopulation (see Figure 5A) inasmuch as FLT1 kinase was shown as a mediator of resistance in HNSCC [48]. Surprisingly, IC50 values for $\mathrm{CD}_{4} 4^{+}$subpopulations were lower than IC50 of primary cell line from which subpopulations were derived. This fact could point out on the important role of CD44-negative cells in the development of resistance; support of $\mathrm{CD} 44^{+}$by $\mathrm{CD} 44^{-}$may be one of the examples. 4 In conclusion, we developed methodics for successful establishement of primary cell lines derived from oral squamous cell carcinoma tissue samples and methodics for removal of mesenchymal (CD90+) cells from this cell line. Separation according to CD44 expression was also successful. CD90/44 status influenced growth rate, sensitivity to cisplatin, and migratory capacity of particular subpopulations derived from the same tumor. Furthermore, non-separated tumor-derived cell lines contained only mesenchymal types of cell after few passages and therefore they are not good model for testing of treatment response of epithelial cancer cells. According to our results, CD90 separation is a necessary step in preparation of permanent HNSCC-tissue derived cell lines. We also presented an indirect cocultivation as an easy and cheap method for evaluation of factors released by distinct subpopulations in tumor, inasmuch as results obtained from direct and indirect settings were comparable. Furthermore, some interesting characteristics of CD44-positive and CD44-negative subpopulations have arisen from our results. Nevertheless, these data are derived only from one HNSCC patient and need further confirmation.

\section{MATERIALS AND METHODS}

\section{Primary culture establishment and culture conditions}

This study was approved by St. Anne University Hospital Ethics Committee (Brno, Czech Republic) and informed consent was obtained from all subjects. All procedures performed in studies involving human participants were in accordance with the ethical standards of the institutional and/or national research committee and with the 1964 Helsinki declaration and its later amendments or comparable ethical standards. Tissue for establishment of the primary cell line were obtained during surgery of patient with oral squamous cell carcinoma (T2N0M0, stage II, grade I) admitted to the Department of Otolaryngology-Head and Neck Surgery, St. Anne's University Hospital.

The first part of tumor tissue material obtained at surgery was placed into RNAlater (Ambion, USA), the second part into culture medium (RPMI 1640, Biochrom, USA) with an addition of $1 \%$ antibiotic-antimycotic solution (Santa Cruz Biotechnology, Texas), $10 \mu \mathrm{g} / \mathrm{ml}$ gentamycin sulphate (Santa Cruz Biotechnology, Texas) and $10 \mu \mathrm{g} / \mathrm{ml}$ ciprofloxacin (Santa Cruz Biotechnology, Texas) to prevent bacteria, fungi and yeast contamination. Within sterile environment and after rinsing the sample by $70 \%$ EtOH (Sigma-Aldrich, Germany), the most viable tissue was selected and any necrotic tissue was discarded. Leavings of EtOH were removed by PBS (Invitrogen, USA) washing. Tissue was mechanically dissociated into small pieces. For proteolysis were used: 1. Trypsin (PAA Laboratories GmbH, Austria) protocol 1 and 2. Collagenase (Sigma-Aldrich, Germany) (protocol 2). 


\section{Protocol 1}

The small tissue fragments were added and stirred into sterile PBS (Invitrogen, USA) and centrifuged at $4^{\circ} \mathrm{C}$, $2700 \mathrm{rpm}$ for $7 \mathrm{~min}$. The cell pellet was re-suspended into $0.25 \%$ trypsin in RPMI 1640 medium and left overnight at $4^{\circ} \mathrm{C}$. Then medium was removed and tissue was incubated at $37^{\circ} \mathrm{C}$ for 30 minutes. The cell pellet was re-suspended in medium with an addition of antibiotic-antimycotic solution, gentamycin sulphate, ciprofloxacin and 10\% FBS. Primary cell lines were cultivated at $37^{\circ} \mathrm{C}$ and $5 \%$ $\mathrm{CO}_{2}$ in humidified atmosphere up to $50 \%$ confluence. As soon as cells were seen attaching to the flask surface, medium was changed. Tumor cells were no longer affected by the use of antibiotic-antimycotic solution, gentamycin sulphate, or ciprofloxacin that were added to the early culture. At this time, cells were grown only in Pen/Strep antibiotic solution (PAA Laboratories $\mathrm{GmbH}$, Austria) in complete medium (penicillin $100 \mathrm{U} \mathrm{ml}^{-1}$ and streptomycin $0.1 \mathrm{mg} \mathrm{ml}^{-1}$; RPMI-1640 medium with $10 \%$ FBS (Biochrom, USA)) (Figure 1).

\section{Protocol 2}

The small tissue fragments were added and stirred into sterile PBS and centrifuged at $4{ }^{\circ} \mathrm{C}, 2700 \mathrm{rpm}$ for $7 \mathrm{~min}$. The cell pellet was resuspended into $4.5 \mathrm{ml}$ of complete culture medium with $0.5 \mathrm{ml}(2000 \mathrm{U} / \mathrm{ml})$ of collagenase. The tissue was incubated at $37^{\circ} \mathrm{C}$ and $5 \%$ $\mathrm{CO}_{2}$ for 72 hours and after that tissue was centrifuged at $4^{\circ} \mathrm{C}, 2700 \mathrm{rpm}$ for $7 \mathrm{~min}$. The cell pellet was resuspended in medium with an addition of antibiotic-antimycotic solution, gentamycin sulphate, ciprofloxacin and 10\% FBS. Primary cell lines were cultivated at $37^{\circ} \mathrm{C}$ and $5 \%$ $\mathrm{CO}_{2}$ in humidified atmosphere up to $50 \%$ confluence.

As soon as cells were seen attaching to the flask surface, medium was changed. Tumor cells were no longer affected by the use of antibiotic-antimycotic solution, gentamycin sulphate, or ciprofloxacin that were added to the early culture. At this time, cells were grown only in Pen/Strep antibiotic solution (PAA Laboratories $\mathrm{GmbH}$, Austria) in complete medium (penicillin $100 \mathrm{U} \mathrm{ml}^{-1}$ and streptomycin $0.1 \mathrm{mg} \mathrm{ml}^{-1}$; RPMI-1640 medium with $10 \%$ FBS (Biochrom, USA)) (Figure 1).

\section{Preparation of subpopulations according to the CD-molecules}

Four cell subpopulations were derived from established HNSCC primary cell culture $\left(\mathrm{CD} 44^{+} / \mathrm{CD}^{+} 0^{+}\right.$;

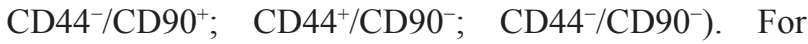
separation of subpopulation derived from primary cell line magnetic particles- MidiMACS ${ }^{\mathrm{TM}}$ Starting Kit (CD44 MicroBeads- human, FcR Blocking Reagent-human, LS Columns; Miltenyi Biotec, Germany) and MiniMACS ${ }^{\mathrm{TM}}$ Starting Kit (CD90 MicroBeads- human, MS Columns; Miltenyi Biotec, Germany) was used.
Dead cells were washed out with $0.5 \mathrm{M}$ EDTA and viable cells were harvested by trypsin. Cell suspension was centrifuged at $300 \times \mathrm{g}$ for 7 minutes at $4^{\circ} \mathrm{C}$. Supernatant was aspirated completely. Cell pelet was resuspended in $1 \mathrm{ml}$ of separating buffer (solution contained phosphate-buffered saline (PBS), $\mathrm{pH} 7.2,0.5 \%$ bovine serum albumin (BSA), and $2 \mathrm{mM}$ EDTA by diluting MACS ${ }^{\circledR}$ BSA Stock Solution 1:20 with autoMACS ${ }^{\circledR}$ Rinsing Solution). Buffer should be kept in cold $\left(2-8^{\circ} \mathrm{C}\right)$. It is important to obtain a single-cell suspension before magnetic labeling. Therefore, cells were passed through $30 \mu \mathrm{m}$ nylon mesh (Pre-Separation Filters $(30 \mu \mathrm{m})$, Miltenyi Biotec, Germany) to remove cell clumps. Cell suspension was centrifuged at $300 \times \mathrm{g}$ for 10 minutes at $4^{\circ} \mathrm{C}$. Supernatant was aspirated. Cell pellet was resuspended in $60 \mu \mathrm{L}$ of buffer and $20 \mu \mathrm{L}$ of FcR Blocking Reagent per $10^{7}$ total cells. Then $20 \mu \mathrm{L}$ of CD44 or CD90 MicroBeads was added. Solution was well mixed and incubated for 15 minutes in the dark in the refrigerator $\left(2-8^{\circ} \mathrm{C}\right)$. Cells were washed by adding $1 \mathrm{~mL}$ of buffer per $10^{7}$ cells and centrifugated at $300 \times \mathrm{g}$ for 10 minutes. Supernatant was aspirated completely. Cell pellet was resuspended in $500 \mu \mathrm{L}$ of separating buffer. LS or MS column was placed in the magnetic field of a MACS Separator. Column was prepared by rinsing with $3 \mathrm{~mL}$ of buffer. Cell suspension was applied onto the column. Flow-through containing unlabeled (CD44 or CD90 non-expressing) cells was collected. Column was washed with $3 \times 3 \mathrm{~mL}$ of buffer. Collected unlabeled cells that pass through were combine with the flow-through from previous step and centrifugated at $300 \times \mathrm{g}$ for 10 minutes. Supernatant was aspirated only $1 \mathrm{~mL}$ of buffer was left. These CD44 or CD90 negative cells were then cultivated in RPMI with 10\% FBS and ATB. Then column was removed from the separator and was placed on a suitable collection tube. $5 \mathrm{~mL}$ of buffer were pipetted onto the column. the magnetically labeled cells were flush out by firmly pushing the plunger into the column. These CD44 or CD90 positive cells were then cultivated in RPMI with $10 \%$ FBS and ATB.

Cells that adhered to the flask were grown in complete medium (RPMI-1640 medium with 10\% FBS, penicillin $100 \mathrm{U} \mathrm{ml}^{-1}$ and streptomycin $0.1 \mathrm{mg} \mathrm{ml}^{-1}$ ) until they reach $70 \%$ confluency, they were then passaged.

\section{CD44 and CD90 fluorescent staining}

At the logarithmic growth phase, cells were stained by CD90 and CD44 antibodies to detect their cell surface marker expression. The cells were washed three times with PBE (0.1 PBS containing $0.5 \%$ bovine serum albumin and 0.002 M EDTA (PAA Laboratories GmbH, Austria); pH 7.2) and stained with CD44-FITC/CD90-APC according to manufacturer's instructions (1:400, Miltenyi Biotec, Germany). Nuclei were co-stained with Hoechst 33258 (2 $\mu \mathrm{M}$, Invitrogen, USA). Nikon Eclipse Ti-S equipped with appropriate set of filters (Japan) was used to visualize the cells. A bar represents $100 \mu \mathrm{m}$. 


\section{Cell number quantification}

Total cell numbers were analysed using the Casy model TT system (Roche, Switzerland) and the following protocol: first, calibration was performed form viable and necrotic cells. For necrotic cells, $100 \mu \mathrm{l}$ cell suspension and $800 \mu \mathrm{l}$ Casy Blue solution was mixed and left for $10 \mathrm{~min}$ at room temperature. Subsequently, $9 \mathrm{ml}$ Casy Tone was added. To prepare a viable cell standard, 100 $\mu \mathrm{l}$ of cell suspension was mixed with $10 \mathrm{ml}$ of Casy Tone. All subsequent measurements were made in $100 \times$ diluted $100 \mu \mathrm{l}$ cell suspension. Prior to each measurement, background was subtracted. All samples were measured in triplicates.

\section{MTT viability assay}

The MTT assay was used to determine cell viability. The suspension of cells in the growth medium was diluted to a density of 2000-10000 cells/column in $200 \mu 1$ medium and transferred to wells $2-11$ of standard microtiter plates. The medium $(200 \mu \mathrm{l})$ was added to the first and to the last column (1 and 12). The plates were incubated for 2 days at $37^{\circ} \mathrm{C}$ to ensure the cell growth. The medium was removed from columns 2 through to 11 . Columns 3-10 were filled with $200 \mu \mathrm{l}$ of the medium containing different concentrations of cisplatin $(0-34 \mu \mathrm{M})$. As a control, columns 2 and 11 were fed with the medium only. The plates were incubated for $48 \mathrm{~h}$. After that, columns 1-11 were fed with $200 \mu \mathrm{l}$ of the medium with $50 \mu \mathrm{l}$ of MTT $(5 \mathrm{mg} / \mathrm{ml}$ in PBS) and incubated for $4 \mathrm{~h}$ in a humidified atmosphere at $37^{\circ} \mathrm{C}$, wrapped in the aluminium foil. After that, the medium was exchanged with $200 \mu 1$ of $99.9 \%$ DMSO to dissolve MTT-formazan crystals. Then, $25 \mu \mathrm{l}$ of glycine buffer was added to all wells with DMSO and the absorbance was recorded at $570 \mathrm{~nm}$ (VersaMax microplate reader, USA).

\section{Real-time impedance based cell growth and proliferation}

The impedance-based real-time cell analysis (RTCA) xCELLigence system was used according to the instructions of the supplier (Roche, Switzerland). Firstly, the optimal seeding concentration for proliferation and cytotoxic assay was determined. Optimal response was found for primary cell line $(2,000$ cells/well $)$ and all subpopulations: $\mathrm{CD}^{+} 4^{+} / \mathrm{CD}^{-} 0^{-}(2,000$ cells/well $)$, $\mathrm{CD}_{4} 4^{+} / \mathrm{CD} 90^{+}\left(1,000\right.$ cells/well) $\mathrm{CD} 44^{-} / \mathrm{CD} 90^{-}(5,000$ cells/well), $\mathrm{CD} 44^{-} / \mathrm{CD} 90^{+}$(2,000 cells/well). After seeding a total number of cells in $200 \mu \mathrm{l}$ of medium to each well in E-plate 16, the attachment and proliferation of the cells were monitored every $15 \mathrm{~min}$. Duration of all experiments was $150 \mathrm{~h}$. Results are expressed as relative impedance. In all of studied subpopulations doubling time was determined by using manufacturer's software.

\section{Preparation of subpopulation-derived media}

$24 \mathrm{~h}$ prior to conducting experiments, $\mathrm{CD}_{4} 4^{-} /$ $\mathrm{CD} 0^{+}, \mathrm{CD} 44^{+} / \mathrm{CD} 90^{+}$and $\mathrm{CD} 44^{+} / \mathrm{CD} 90^{-}$cells were trypsinized. 50,000 cells $/ \mathrm{ml}$ of each cell line were cultured in $75 \mathrm{~cm}^{2}$ flasks with medium. Media were removed from cultures after $24 \mathrm{~h}$ and used for the experiments.

\section{Indirect co-culture}

The rate of proliferation was monitored in real time using xCELLigence system (E-plate). $2000 \mathrm{CD} 44^{+} /$ $\mathrm{CD}^{-}{ }^{-}$cells per well were seeded in the E-plate 16. After $24 \mathrm{~h}$ of impedance reading, medium was removed from each well and replaced by media derived from foreign subpopulations $\left(\mathrm{CD} 44^{-} / \mathrm{CD} 90^{+}, \mathrm{CD} 44^{+} / \mathrm{CD} 90^{+}\right)$and by control medium derived from the same subpopulation $\left(\mathrm{CD} 44^{+} / \mathrm{CD} 90^{-}\right)$or by fresh RPMI medium. Impedance value was automatically monitored by the system for 200 h. This experiment was performed in duplicates.

Furthermore, determining of changes in gene expression after incubation with medium derived from foreign subpopulation was performed. The $\mathrm{CD} 44^{+} / \mathrm{CD} 90^{-}$ cells were cultivated at $37^{\circ} \mathrm{C}$ and $5 \% \mathrm{CO}_{2}$ in humidified atmosphere up to $70 \%$ confluence. After $24 \mathrm{~h}$ medium was removed and replaced with foreign media: a) $\mathrm{CD}_{4} 4^{-}$ $\mathrm{CD} 90^{+}$, b) $\mathrm{CD}_{4} 4^{+} / \mathrm{CD} 90^{+}$and c) by control medium $\left(\mathrm{CD} 44^{+} / \mathrm{CD} 90^{-}\right)$. The experiment has been performed for $72 \mathrm{~h}$ than the relative expression of 15 genes related to HNSCC pathogenesis was determined by using qRT-PCR in all of these cases.

\section{Direct co-culture}

The rate of proliferation was monitored in real time using xCELLigence system (E-plate and E-insert). 2000 $\mathrm{CD} 44^{+} / \mathrm{CD} 90^{-}$cells per well were seeded in the E-plate 16. $\mathrm{CD} 44^{+} / \mathrm{CD} 90^{-}, \mathrm{CD} 44^{+} / \mathrm{CD} 90^{+}$and $\mathrm{CD} 44^{-} / \mathrm{CD} 90^{+}$cells were seeded into insert at the density of 15000 cells per well. After $24 \mathrm{~h}$ of incubation at $37^{\circ} \mathrm{C}$ and $5 \% \mathrm{CO}_{2}$ the insert was lowered into the E-plate. Impedance value was automatically monitored by the system for $140 \mathrm{~h}$. This experiment was performed in duplicates.

\section{ELISA analysis}

Levels of EGFR and MMP2 in homogenized cells were determined by commercial enzyme-linked immunosorbent assay (ELISA) kits (RayBiotech, USA) according to the manufacturer's instructions. The EGFRELISA is designed to detect human EGFR with a detection limit $4 \mathrm{pg} / \mathrm{ml}$, a $10 \%$ intra-assay, and a $12 \%$ inter-assay variability. The EGFR antibodies were raised against the L25-S645 region of EGFR. The MMP2-ELISA is designed to detect human MMP2 with a detection limit $3500 \mathrm{pg} / \mathrm{ml}$, a $10 \%$ intra-assay, and a $12 \%$ inter-assay variability. 


\section{RNA isolation and reverse transcription}

TriPure Isolation Reagent (Roche, Basel, Switzerland) was used for RNA isolation. The isolated RNA was used for cDNA synthesis. RNA (1000 ng) was transcribed using transcriptor first strand cDNA synthesis kit (Roche, Switzerland), which was applied according to manufacturer's instructions. The cDNA $(20 \mu l)$ prepared from the total RNA was diluted with RNase free water to $100 \mu \mathrm{l}$ and the amount of $5 \mu \mathrm{l}$ was directly analysed by using the LightCycler ${ }^{\circledR} 480$ II System (Roche, Basel, Switzerland).

\section{Quantitative real-time polymerase chain reaction}

qRT-PCR was performed using the TaqMan gene expression assays with the LightCycler ${ }^{\circledR} 480$ II System (Roche, Basel, Switzerland) and the amplified DNA was analysed by the comparative $\mathrm{Ct}$ method using $\beta$-actin as an endogenous control. The primer and probe sets for ACTB (assay ID: Hs99999903_m1), MT2A (Hs02379661_g1), MT1A (Hs00831826 s1), TP53 (Hs01034249 m1), BAX (Hs00180269 m1), BCL2 (Hs00608023 m1), VEGFA (Hs00900055_m1), FLT1 (Hs01052961_m1), MMP2 (Hs01548727_m1), FOS (Hs00170630_m1), JUN (Hs00277190_s1), MKI67 (Hs00606991_m1), EGF (Hs01099999_m1), EGFR (Hs01076078_m1), SOX2 (Hs01053049_s1), NFkB1 (Hs00765730_m1), BECN1 (Hs00186838_m1), HIF1A (Hs00153153_m1), MAP1LC3B (Hs00797944_s1), NANOG (Hs04260366 g1), CAV1 (Hs00971716 m1), MTOR (Hs00234508 m1), CCL2 (Hs00907239 m1), ZIP1 (also known as SLC39A1) (Hs00205358 m1), BIRC5 (Hs00153353 m1), IL6 (Hs00985639_m1), IL6R (Hs01075666_m1), and POU5F1 (Hs04260367 gH) were selected from TaqMan gene expression assays (Life Technologies, USA). qRTPCR was performed under the following amplification conditions: total volume of $20 \mu \mathrm{l}$, initial incubation at $50^{\circ} \mathrm{C} / 2 \mathrm{~min}$ followed by denaturation at $95^{\circ} \mathrm{C} / 10 \mathrm{~min}$, then 45 cycles at $95^{\circ} \mathrm{C} / 15 \mathrm{sec}$ and at $60^{\circ} \mathrm{C} / 1 \mathrm{~min}$. Gene expression experiments were performed in duplicates

\section{Wound healing assay}

After passage each cell line was resuspended and seeded into 24-well plate, the cell amount per well in 500 $\mu \mathrm{l}$ media was optimized to 60,000 for $\mathrm{CD} 44^{+} / \mathrm{CD} 90^{+}$, 50,000 for $\mathrm{CD}_{4} 4^{+} / \mathrm{CD} 90^{-}, 40,000$ for $\mathrm{CD}_{4} 4^{-} / \mathrm{CD}^{-} 0^{-}$and 45,000 for $\mathrm{CD}_{4} 4^{-} / \mathrm{CD} 90^{+}$. After $48 \mathrm{~h}$ the cells were $100 \%$ confluent and the scratch into the cell monolayer was made. After gentle wash and change of media each well was photographed at time 0 and after $24 \mathrm{~h}$ at the very same spot. The photos were analysed according to instructions from the software creator [49]. The software computed the percent of open wound area. Each cell line was analysed in at least 24 repetitions.

\section{Flow cytometric analysis of cell death}

Double-staining with fluorescein isothiocyanate (FITC)/propidium iodide (PI) was undertaken using the Annexin V-FLUOS-staining kit (Roche Applied Science) according to the manufacturer's protocol in order to determine percentages of viable, apoptotic and necrotic cells. Briefly, the cells were harvested by repetitive pipetting and washed two times with PBS (centrifuged at $2000 \mathrm{rpm}$ for $5 \mathrm{~min}$ ), resuspended in $100 \mu \mathrm{l}$ of AnnexinV-FLUOS labelling solution and incubated in the dark at $15-25^{\circ} \mathrm{C}$ (15 min.). Annexin V-FITC fluorescence was detected by flow cytometry (Partec $\mathrm{GmbH}$, Münster, Germany); (FL1 filter for Annexin-V-FLUOS and FL3 filter for PI).

\section{Flow cytometric detection of autophagosomes}

Autophagosome formation in subpopulations were detected using the CYTO-ID Autophagy Detection Kit (Enzo, PA, USA) following the manufacturer's instruction. The CYTO-ID green fluorescent reagents specifically detect acid autophagic vacuoles formed during autophagy. Briefly, the cells were harvested by gentle repetitive pipetting, spun down and washed twice in RPMI 1640 with 5\% fetal bovine serum (FBS), then were centrifuged at $2000 \mathrm{rpm}$ for $5 \mathrm{~min}$. The cells were resuspended in $500 \mu \mathrm{l}$ of freshly diluted CYTO-ID staining reagent and incubated in the dark at $37^{\circ} \mathrm{C}$ for $30 \mathrm{~min}$. CYTO-ID fluorescence of cells was immediately analysed by flow cytometry using the flow cytometry (Partec $\mathrm{GmbH}$, Münster, Germany) (FL1 filter for CYTO-ID, SSC for cellular granularity). The percentage of cells with CYTO-ID staining was used to represent the formation of autophagosomes.

\section{HPV detection}

The 142 base-pair long sequence of conservative $L 1$ gene was amplified using GP5 and GP6 primers for nonspecific identification of HPV-positive subjects. The PCR mixture from New England Biolabs (UK), contained PCR buffer $(10 \mathrm{mM}$ Tris $\mathrm{HCl}, \mathrm{pH} 8.3,50 \mathrm{mM} \mathrm{KCl}$ with 2.5 $\mathrm{mM} \mathrm{MgCl}$ included) $0.05 \mathrm{mM}$ of each dNTP and 0.05 mM of GP5 (5'-TTTGTTACTGTGGTAGATAC-3') and GP6 (5'-GAAAAATAAACTGTAAATCA-3') primers. The DNA amplification was carried out during 40 cycles that included the denaturation at $94^{\circ} \mathrm{C}$ for $30 \mathrm{~s}$, annealing at $45^{\circ} \mathrm{C}$ for $30 \mathrm{~s}$ and the primer extension at $72^{\circ} \mathrm{C}$ for $30 \mathrm{~s}$.

The HPV-positive specimens were further analysed with the HPV16 (FOR primer: 5'-CCCAGCTGTAATCATGCATGGAGA-3'; REV primer: 5'-GTGTGCCCATTAACAGGTCTTCCA-3') and HPV18 (FOR primer: 5'-CGACAGGAACGACTCCAACGA-3'; REV primer: $5^{\circ}$-GCTGGTAAATGTTGATGATTAACT-3') primers. The PCR amplicons reached length of 202 bp for HPV16 
and $272 \mathrm{bp}$ for HPV18. The DNA amplification was carried out during 40 cycles that included the denaturation at 94 ${ }^{\circ} \mathrm{C}$ for $30 \mathrm{~s}$, the annealing at $58^{\circ} \mathrm{C}$ for $30 \mathrm{~s}$ and the primer extension at $72^{\circ} \mathrm{C}$ for $30 \mathrm{~s}$. As internal quality control of the isolated DNA, $\beta$-actin gene (600 bp) was amplified (FOR primer: 5'CCTGAACCCTAAGGCCAACC3'; REV primer: 5'GCAATGCCTGGGTACATGGT3'). Each PCR product was analysed using electrophoresis on $1 \%$ agarose gels stained with ethidium bromide.

\section{Statistical analysis}

Pearson correlation and cluster analysis were performed to reveal associations between cases and variables. These analyses were performed on standardized data; the cluster analysis was performed using Ward's method. Data were analysed using factorial ANOVA following planned comparisons. All charts are depicted with means and standard deviations. $\mathrm{P}$ value $<0.05$ was considered significant. Software Statistica (StatSoft, Tulsa, OK, USA) was used for analysis. The annotation analyses were performed using the GoMiner (http://discover.nci.nih.gov/gominer/index. jsp), interactome network was constructed using the STRING software (http://string-db.org/) using Kyoto Encyclopedia of Genes and Genomes (KEGG) pathway database (http://www.genome.jp/kegg/), which provides gold standard sets of molecular pathways.

\section{Author contributions}

MS wrote manuscript, coordinated lab experiments, performed tissue culture experiments; MR wrote manuscript, performed gene expression analysis; JG analysed results, performed statistics; JB performed flow cytometry; MF performed MTT; MK performed real time cell growth experiments, cell migration analysis; HP performed ELISA.

ZHor. performed biopsies, work with patient; RK provided clinical feedback; PB performed microscopy; ZHeg. pefromed HPV detection; MM designed experiment.

\section{ACKNOWLEDGMENTS}

We acknowledge that patway analyses of gene expression data were performed by Miguel Angel Merlos Rodrigo from Department of Chemistry and Biochemistry, Mendel University in Brno, Czech republic.

\section{CONFLICTS OF INTEREST}

The authors declare no conflicts of interest.

\section{FUNDING}

This work was supported by the Ministry of Health of the Czech Republic (16-29835A), by the Grant Agency of the Czech Republic (GA16-12454S), by the Ministry of Education, Youth and Sports of the Czech Republic under the project CEITEC 2020 (LQ1601) and by funds from the Faculty of Medicine, Masaryk University to junior researcher (Michal Masarik).

\section{REFERENCES}

1. Gregoire V, Lefebvre JL, Licitra L, Felip E; EHNSESMO-ESTRO Guidelines Working Group. Squamous cell carcinoma of the head and neck: EHNS-ESMO-ESTRO Clinical Practice Guidelines for diagnosis, treatment and follow-up. Ann Oncol. 2010; 21:v184-6. https://doi. org/10.1093/annonc/mdq185.

2. Bragado P, Estrada Y, Sosa MS, Avivar-Valderas A, Cannan D, Genden E, Teng M, Ranganathan AC, Wen HC, Kapoor A, Bernstein E, Aguirre-Ghiso JA. Analysis of marker-defined HNSCC subpopulations reveals a dynamic regulation of tumor initiating properties. PLoS One. 2012; 7:e29974. https://doi.org/10.1371/journal.pone.0029974.

3. Reers S, Pfannerstill AC, Maushagen R, Pries R, Wollenberg B. Stem cell profiling in head and neck cancer reveals an Oct-4 expressing subpopulation with properties of chemoresistance. Oral Oncol. 2014; 50:155-62. https:// doi.org/10.1016/j.oraloncology.2013.12.006.

4. Tang KH, Dai YD, Tong M, Chan YP, Kwan PS, Fu L, Qin YR, Tsao SW, Lung HL, Lung ML, Tong DK, Law S, Chan KW, et al. A CD90(+) tumor-initiating cell population with an aggressive signature and metastatic capacity in esophageal cancer. Cancer Res. 2013; 73:2322-32.

5. Satpute PS, Hazarey V, Ahmed R, Yadav L. Cancer stem cells in head and neck squamous cell carcinoma: a review. Asian Pac J Cancer Prev. 2013; 14:5579-87. https://doi. org/10.7314/apjcp.2013.14.10.5579.

6. Major AG, Pitty LP, Farah CS. Cancer stem cell markers in head and neck squamous cell carcinoma. Stem Cells Int. 2013. https://doi.org/10.1155/2013/319489.

7. Ponta H, Sherman L, Herrlich PA. CD44: from adhesion molecules to signalling regulators. Nat Rev Mol Cell Biol. 2003; 4:33-45. https://doi.org/10.1038/nrm1004.

8. Perez A, Neskey DM, Wen J, Pereira L, Reategui EP, Goodwin WJ, Carraway KL, Franzmann EJ. CD44 interacts with EGFR and promotes head and neck squamous cell carcinoma initiation and progression. Oral Oncol. 2013; 49:306-13. https://doi.org/10.1016/j. oraloncology.2012.11.009.

9. Al-Hajj M, Wicha MS, Benito-Hernandez A, Morrison SJ, Clarke MF. Prospective identification of tumorigenic breast cancer cells. Proc Natl Acad Sci U S A. 2003; 100:3983-8. https://doi.org/10.1073/pnas.0530291100.

10. Gunthert U, Hofmann M, Rudy W, Reber S, Zoller M, Haussmann I, Matzku S, Wenzel A, Ponta H, Herrlich P. A new variant of glycoprotein CD44 confers metastatic potential to rat carcinoma-cells. Cell. 1991; 65:13-24. https://doi.org/10.1016/0092-8674(91)90403-1. 
11. La Fleur L, Johansson AC, Roberg K. A CD44(high)/ EGFR(low) subpopulation within head and neck cancer cell lines shows an epithelial-mesenchymal transition phenotype and resistance to treatment. PLoS One. 2012; 7:e44071. https://doi.org/e44071 10.1371/journal.pone.0044071.

12. Janisiewicz AM, Shin JH, Murillo-Sauca O, Kwok S, Le QT, Kong C, Kaplan MJ, Sunwoo JB. CD44+cells have cancer stem cell-like properties in nasopharyngeal carcinoma. Int Forum Allergy Rhinol. 2012; 2:465-70. https://doi.org/10.1002/alr.21068.

13. Lim YC, Oh SY, Cha YY, Kim SH, Jin X, Kim H. Cancer stem cell traits in squamospheres derived from primary head and neck squamous cell carcinomas. Oral Oncol. 2011; 47:83-91. https://doi.org/10.1016/j. oraloncology.2010.11.011.

14. Prince ME, Sivanandan R, Kaczorowski A, Wolf GT, Kaplan MJ, Dalerba P, Weissman IL, Clarke MF, Ailles LE. Identification of a subpopulation of cells with cancer stem cell properties in head and neck squamous cell carcinoma. Proc Natl Acad Sci U S A. 2007; 104:973-8. https://doi. org/10.1073/pnas.0610117104.

15. Kidwai F, Costea DE, Hutchison I, Mackenzie I. The effects of CD44 down-regulation on stem cell properties of head and neck cancer cell lines. J Oral Pathol Med. 2013; 42:68290. https://doi.org/10.1111/jop.12076.

16. Kinugasa Y, Matsui T, Takakura N. CD44 expressed on cancer-associated fibroblasts is a functional molecule supporting the stemness and drug resistance of malignant cancer cells in the tumor microenvironment. Stem Cells. 2014; 32:145-56. https://doi.org/10.1002/stem.1556.

17. True LD, Zhang H, Ye M, Huang CY, Nelson PS, von Haller PD, Tjoelker LW, Kim JS, Qian WJ, Smith RD, Ellis WJ, Liebeskind ES, Liu AY. CD90/THY1 is overexpressed in prostate cancer-associated fibroblasts and could serve as a cancer biomarker. Mod Pathol. 2010; 23:1346-56. https:// doi.org/10.1038/modpathol.2010.122.

18. Ko KS, Arora PD, McCulloch CA. Cadherins mediate intercellular mechanical signaling in fibroblasts by activation of stretch-sensitive calcium-permeable channels. J Biol Chem. 2001; 276:35967-77. https://doi.org/10.1074/ jbc.M104106200.

19. Liotta F, Querci V, Mannelli G, Santarlasci V, Maggi L, Capone M, Rossi MC, Mazzoni A, Cosmi L, Romagnani S, Maggi E, Gallo O, Annunziato F. Mesenchymal stem cells are enriched in head neck squamous cell carcinoma, correlates with tumour size and inhibit T-cell proliferation. Br J Cancer. 2015; 112:745-54. https://doi.org/10.1038/ bjc.2015.15.

20. Lu H, Clauser KR, Tam WL, Froese J, Ye X, Eaton EN, Reinhardt F, Donnenberg VS, Bhargava R, Carr SA, Weinberg RA. A breast cancer stem cell niche supported by juxtacrine signalling from monocytes and macrophages. Nat Cell Biol. 2014; 16:1105-17. https://doi.org/10.1038/ ncb3041.
21. Pries R, Wittkopf N, Hasselbacher K, Wollenberg B. [Constitutive expression of the potential stem cell marker CD44 in permanent HNSCC cell lines]. [Article in German]. HNO. 2008; 56:461-6. https://doi.org/10.1007/ s00106-008-1707-0.

22. Lin CJ, Grandis JR, Carey TE, Gollin SM, Whiteside TL, Koch WM, Ferris RL, Lai SY. Head and neck squamous cell carcinoma cell lines: established models and rationale for selection. Head Neck. 2007; 29:163-88. https://doi. org/10.1002/hed.20478.

23. Zhao H, Peehl DM. Tumor-promoting phenotype of CD90(hi) prostate cancer-associated fibroblasts. Prostate. 2009; 69:991-1000. https://doi.org/10.1002/pros.20946.

24. Spaeth EL, Labaff AM, Toole BP, Klopp A, Andreeff M, Marini FC. Mesenchymal CD44 expression contributes to the acquisition of an activated fibroblast phenotype via TWIST activation in the tumor microenvironment. Cancer Res. 2013; 73:5347-59. https://doi.org/10.1158/0008-5472. can-13-0087.

25. Shan J, Shen J, Liu L, Xia F, Xu C, Duan G, Xu Y, Ma Q, Yang Z, Zhang Q, Ma L, Liu J, Xu S, et al. Nanog regulates self-renewal of cancer stem cells through the insulin-like growth factor pathway in human hepatocellular carcinoma. Hepatology. 2012; 56:1004-14. https://doi.org/10.1002/ hep. 25745.

26. Fukuda S, Pelus LM. Survivin, a cancer target with an emerging role in normal adult tissues. Mol Cancer Ther. 2006; 5:1087-98. https://doi.org/10.1158/1535-7163. mct-05-0375.

27. Dutsch-Wicherek M, Lazar A, Tomaszewska R, Kazmierczak W, Wicherek L. Analysis of metallothionein and vimentin immunoreactivity in pharyngeal squamous cell carcinoma and its microenvironment. Cell Tissue Res. 2013; 352:341-9. https://doi.org/10.1007/s00441-013-1566-1.

28. Kim SY, Kang JW, Song X, Kim BK, Yoo YD, Kwon YT, Lee YJ. Role of the IL-6-JAK1-STAT3-Oct-4 pathway in the conversion of non-stem cancer cells into cancer stem-like cells. Cell Signal. 2013; 25:961-9. https://doi. org/10.1016/j.cellsig.2013.01.007.

29. Qian BZ, Li J, Zhang H, Kitamura T, Zhang J, Campion LR, Kaiser EA, Snyder LA, Pollard JW. CCL2 recruits inflammatory monocytes to facilitate breast-tumour metastasis. Nature. 2011; 475:222-5. https://doi. org/10.1038/nature10138.

30. Lee CC, Ho HC, Su YC, Lee MS, Hung SK, Lin CH. MCP1-induced epithelial-mesenchymal transition in head and neck cancer by AKT activation. Anticancer Res. 2015; 35:3299-306.

31. Bonapace L, Coissieux MM, Wyckoff J, Mertz KD, Varga Z, Junt T, Bentires-Alj M. Cessation of CCL2 inhibition accelerates breast cancer metastasis by promoting angiogenesis. Nature. 2014; 515:130-3. https://doi. org/10.1038/nature13862. 
32. Zhang GT, Tsang CM, Deng W, Yip YL, Lui VW, Wong SC, Cheung AL, Hau PM, Zeng MS, Lung ML, Chen HL, Lo KW, Takada K, Tsao SW. Enhanced IL-6/IL-6R signaling promotes growth and malignant properties in EBV-infected premalignant and cancerous nasopharyngeal epithelial cells. PLoS One. 2013; 8:e62284. https://doi.org/10.1371/journal. pone.0062284.

33. Chen MF, Wang WH, Lin PY, Lee KD, Chen WC. Significance of the TGF-beta I/IL-6 axis in oral cancer. Clin Sci. 2012; 122:459-72. https://doi.org/10.1042/cs20110434.

34. Sun X, Mao Y, Wang J, Zu L, Hao M, Cheng G, Qu Q, Cui D, Keller ET, Chen X, Shen K. IL-6 secreted by cancer-associated fibroblasts induces tamoxifen resistance in luminal breast cancer. Oncogene. 2014. https://doi. org/10.1038/onc.2014.158.

35. Dufour A, Sampson NS, Zucker S, Cao J. Role of the hemopexin domain of matrix metalloproteinases in cell migration. J Cell Physiol. 2008; 217:643-51. https://doi. org/10.1002/jcp.21535.

36. Dufour A, Zucker S, Sampson NS, Kuscu C, Cao J. Role of matrix metalloproteinase-9 dimers in cell migration: design of inhibitory peptides. J Biol Chem. 2010; 285:35944-56. https://doi.org/10.1074/jbc.M110.091769.

37. Chetty C, Lakka SS, Bhoopathi P, Rao JS. MMP-2 alters VEGF expression via alpha $\mathrm{V}$ beta 3 integrin-mediated $\mathrm{PI} 3 \mathrm{~K} / \mathrm{AKT}$ signaling in A549 lung cancer cells. Int J Cancer. 2010; 127:1081-95. https://doi.org/10.1002/ijc.25134.

38. Yang X, Zhu HC, Ge YY, Liu J, Cai J, Qin Q, Zhan LL, Zhang C, Xu LP, Liu ZM, Yang Y, Yang YH, Ma JX, et al. Melittin enhances radiosensitivity of hypoxic head and neck squamous cell carcinoma by suppressing HIF-1 alpha. Tumor Biol. 2014; 35:10443-8. https://doi.org/10.1007/ s13277-014-2218-0.

39. Ruttkay-Nedecky B, Nejdl L, Gumulec J, Zitka O, Masarik M, Eckschlager T, Stiborova M, Adam V, Kizek R. The role of metallothionein in oxidative stress. Int J Mol Sci. 2013; 14:6044-66. https://doi.org/10.3390/ijms14036044.

40. Lu ZM, Ghosh S, Wang ZY, Hunter T. Downregulation of caveolin-1 function by EGF leads to the loss of E-cadherin, increased transcriptional activity of beta-catenin, and enhanced tumor cell invasion. Cancer Cell. 2003; 4:499515. https://doi.org/10.1016/s1535-6108(03)00304-0.
41. Masood R, Hochstim C, Cervenka B, Zu S, Baniwal SK, Patel V, Kobielak A, Sinha UK. A novel orthotopic mouse model of head and neck cancer and lymph node metastasis. Oncogenesis. 2013; 2:e68. https://doi.org/10.1038/ oncsis.2013.33.

42. Ha TK, Chi SG. CAV1/caveolin 1 enhances aerobic glycolysis in colon cancer cells via activation of SLC2A3/ GLUT3 transcription. Autophagy. 2012; 8:1684-5. https:// doi.org/10.4161/auto.21487.

43. Wang Q, Wu PC, Roberson RS, Luk BV, Ivanova I, Chu E, $\mathrm{Wu} \mathrm{DY}$. Survivin and escaping in therapy-induced cellular senescence. Int J Cancer. 2011; 128:1546-58. https://doi. org/10.1002/ijc.25482.

44. Yang S, Wang X, Contino G, Liesa M, Sahin E, Ying H, Bause A, Li Y, Stommel JM, Dell'Antonio G, Mautner J, Tonon G, Haigis M, et al. Pancreatic cancers require autophagy for tumor growth. Genes Dev. 2011; 25:717-29. https://doi.org/10.1101/gad.2016111.

45. Theunissen TW, Silva JC. Switching on pluripotency: a perspective on the biological requirement of Nanog. Philos Trans R Soc Lond B Biol Sci. 2011; 366:2222-9. https://doi. org/10.1098/rstb.2011.0003.

46. Lynch L, O'Donoghue D, Dean J, O'Sullivan J, O'Farrelly C, Golden-Mason L. Detection and characterization of hemopoietic stem cells in the adult human small intestine. J Immunol. 2006; 176:5199-204.

47. Mitchell R, Szabo E, Shapovalova Z, Aslostovar L, Makondo K, Bhatia M. Molecular evidence for OCT4induced plasticity in adult human fibroblasts required for direct cell fate conversion to lineage specific progenitors. Stem Cells. 2014; 32:2178-87. https://doi.org/10.1002/ stem.1721.

48. Van Limbergen EJ, Zabrocki P, Porcu M, Hauben E, Cools $\mathrm{J}$, Nuyts S. FLT1 kinase is a mediator of radioresistance and survival in head and neck squamous cell carcinoma. Acta Oncol. 2014; 53:637-45. https://doi.org/10.3109/028 4186x.2013.835493.

49. Gebaeck T, Schulz MM, Koumoutsakos P, Detmar M. TScratch: a novel and simple software tool for automated analysis of monolayer wound healing assays. Biotechniques. 2009; 46:265-74. https://doi.org/10.2144/000113083. 